\title{
Disturbance Related to Unconventional Oil and Gas Development in the Appalachian Basin
}

\author{
Kevin Jordan Harris \\ West Virginia University, kjh0006@mix.wvu.edu
}

Follow this and additional works at: https://researchrepository.wvu.edu/etd

Part of the Natural Resources and Conservation Commons, and the Oil, Gas, and Energy Commons

\section{Recommended Citation}

Harris, Kevin Jordan, "Disturbance Related to Unconventional Oil and Gas Development in the Appalachian Basin" (2020). Graduate Theses, Dissertations, and Problem Reports. 7548.

https://researchrepository.wvu.edu/etd/7548

This Thesis is protected by copyright and/or related rights. It has been brought to you by the The Research Repository @ WVU with permission from the rights-holder(s). You are free to use this Thesis in any way that is permitted by the copyright and related rights legislation that applies to your use. For other uses you must obtain permission from the rights-holder(s) directly, unless additional rights are indicated by a Creative Commons license in the record and/ or on the work itself. This Thesis has been accepted for inclusion in WVU Graduate Theses, Dissertations, and Problem Reports collection by an authorized administrator of The Research Repository @ WVU. For more information, please contact researchrepository@mail.wvu.edu. 


\title{
Disturbance Related to Unconventional Oil and Gas Development in the Appalachian Basin
}

\author{
Kevin J. Harris \\ Thesis submitted \\ to the Davis College of Agriculture, Natural Resources and Design \\ at West Virginia University \\ in partial fulfillment of the requirements for the degree of \\ Master of Science in \\ Forestry \\ Shawn Grushecky, Ph.D., Chair \\ Jingxin Wang, Ph.D. \\ Michael Strager, Ph.D. \\ Division of Forestry and Natural Resources \\ Morgantown, West Virginia \\ 2020
}

Keywords: unconventional drilling, natural gas, land cover

Copyright 2020 Kevin Harris 


\section{Abstract}

Disturbance Related to Unconventional Oil and Gas Development in the Appalachian Basin

Kevin J. Harris

Little research has been done on the land cover change of unconventional oil and gas (UOG) wells across the Appalachian basin. In the last decade, UOG development has increased drastically across the region. Permitted well data from 2007 to 2017 were assembled into a geospatial database and analyzed with current aerial imagery to determine the activity of permitted wells in Ohio, Pennsylvania, and West Virginia. To capture all disturbance related to UOG development, a 25-hectare buffer was placed around each active well as the study extent. A supervised classification approach was used to determine the pre-development and postdevelopment landcover across all 4,212 well pad buffers in the region. Overall, the average forested and grass land cover percentage decreased by 4.3 and 0.8 percent across the Appalachian basin, while the impervious surface percentage gained an average of 5.2 percent respectively. The largest land cover change category was forest to grass, with an average of 3.8 hectares per well pad buffer across the region. Forest and grass land cover changed to impervious land cover by an average of 0.8 and 0.9 hectares per well buffer. The trend suggests that well pads are currently being placed in areas with higher grass landcover. Thus as development continues in the region, results indicate that impacts could increase in more forested cover types. 


\section{Table of Contents}

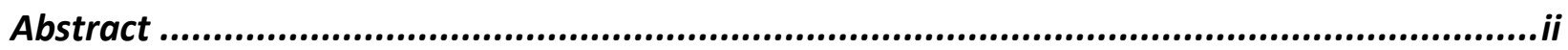

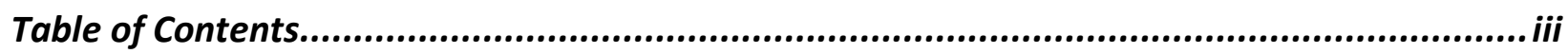

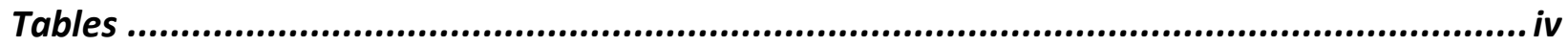

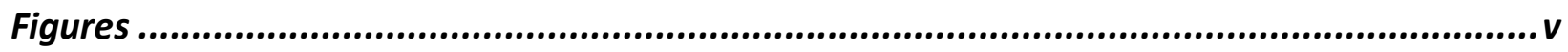

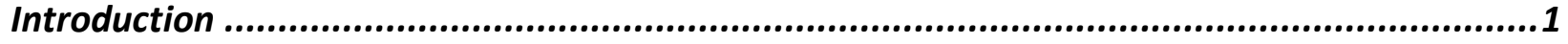

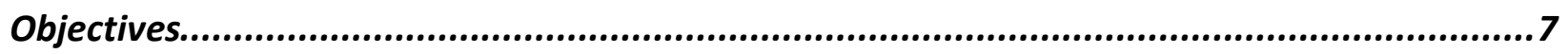

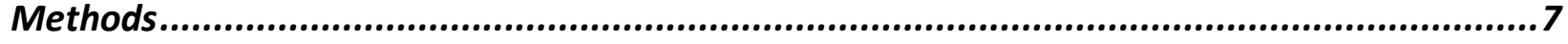

Unconventional Development in the Appalachian Basin ............................................................

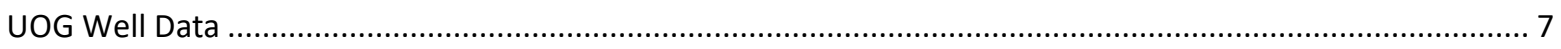

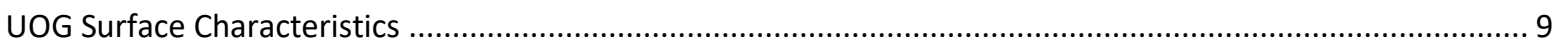

Land Cover Characteristics Associated with UOG Development ...............................................12

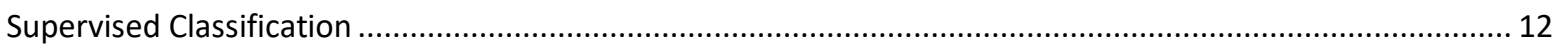

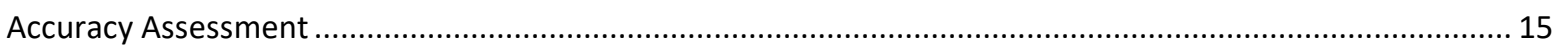

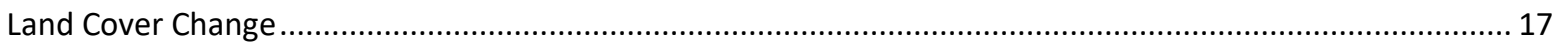

Pre and Future Development Land Cover Characteristics ....................................................19

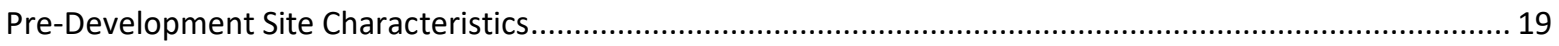

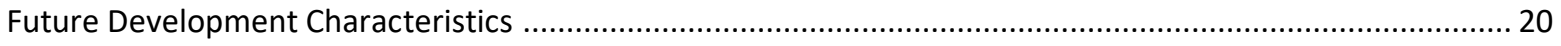

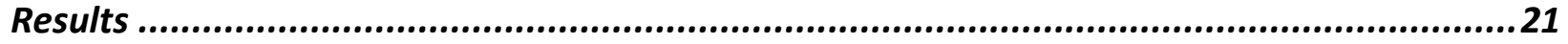

Unconventional Development in the Appalachian Basin ...........................................................21

Land Cover Characteristics Associated with UOG Development ...................................................23

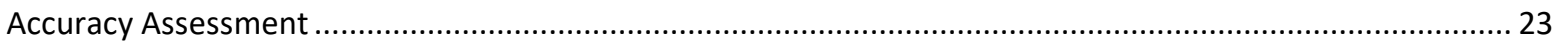

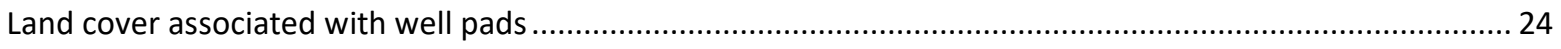

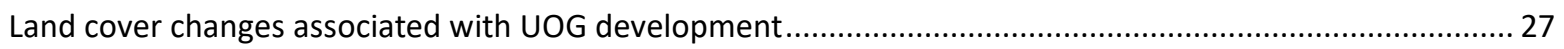

Pre and Future Development Land Cover Characteristics ..........................................................31

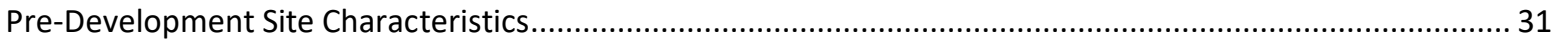

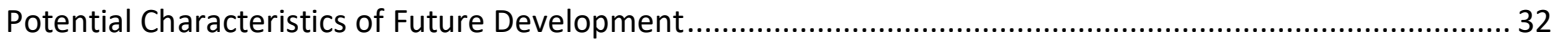

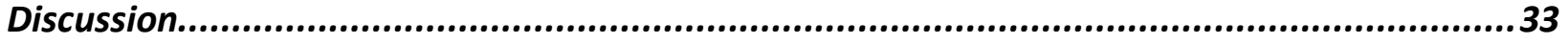

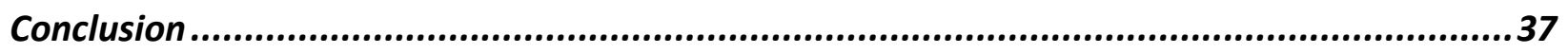

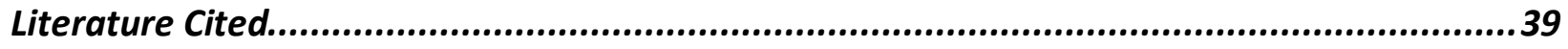

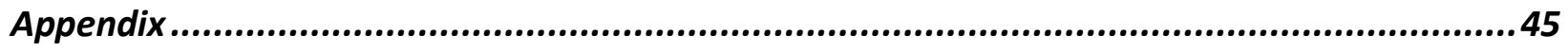




\section{Tables}

Table 1: Years of NAIP imagery utilized in the analysis. ....................................................... 10 Table 2: Accuracy assessment of the supervised classification for the post-development time, using 2017 NAIP imagery, for Ohio. Reference numbers represent the ground reference data, while the map numbers represent the classification of each image pixel. 16

Table 3: Nine potential types of land cover change in the Appalachian basin between 2007 and 2017. 18

Table 4: Accuracy assessment of the supervised classification for the pre-development time, using 2007 NAIP imagery, for West Virginia. Reference numbers represent the ground reference data, while the map numbers represent the classification of each image pixel.

Table 5: Accuracy assessment of the supervised classification for the pre-development time, using 2008 NAIP imagery, for Pennsylvania. Reference numbers represent the ground reference data, while the map numbers represent the classification of each image pixel. .........2 24

Table 6: Land cover proportion of the well pad buffers in the Appalachian basin.......................25

Table 7: Pre-development land cover percentage by state across the Appalachian basin. ....... 26

Table 8: Post-development land cover percentage by state across the Appalachian basin....... 26

Table 9: Land cover change across Pennsylvania in acres, showing only those counties with 10 or more buffers.

Table 10: Pre-development land cover, in percent, of areas within the random 25-ha buffers.

The counties selected are the county with the most wells drilled per state

Table 11: Land cover percentage of areas that have not been developed, as of 2017. The counties selected are the county with the most wells drilled per state. 


\section{Figures}

Figure 1: The Marcellus and Utica shale plays underlay much of the Appalachian basin (U.S. Energy Information Administration, 2016).

Figure 2: Conventional wells are typically drilled vertically, while unconventional wells are drilled both vertically and horizontally (U.S. Energy Information Administration, 2019c)....

Figure 3: The flowchart of the steps taken to determine land cover on well sites throughout the study area.

Figure 4: NAIP imagery from 2017 and supervised classification results from an unconventional well pad in West Virginia. Imagery was classified into forest, grass, and impervious surface using the maximum likelihood classifier tool within ArcGIS.

Figure 5: Known UOG well lateral directions and lengths from WVDEP (2020).....................20

Figure 6: The geographical location of all active wells, which were used in the study ............. 23 Figure 7: The average land cover disturbance (ha), per well pad, associated with UOG development across the Appalachian basin 


\section{Introduction}

In 2018, over 30 trillion cubic feet (Tcf) of natural gas was consumed within the United States (U.S. Energy Information Administration, 2019a). Natural gas production rose to an alltime high of 10 billion cubic feet per day (Bcf/d) in 2018, which is an 11 percent increase from 2017 (Geary, 2019). The rise in unconventional drilling across the United States has led to an increased production of oil and natural gas which have previously been locked inside tight sandstones, shales, and other low-permeability geologic formations (Jackson et al., 2014). As of September 2018, the US exported more natural gas by pipeline than it imported by pipeline for the first time in nearly 20 years (Geary, 2019).

The Marcellus and Utica shale play in the Appalachian basin, are just two of the shale plays being explored for natural gas production in the United States. The Utica shale play covers an area of $298 \mathrm{~km}^{2}\left(115,000 \mathrm{mi}^{2}\right)$, while the Marcellus covers an area of $240,000 \mathrm{~km}^{2}$ $\left(95,000 \mathrm{mi}^{2}\right)$ respectively (Kargbo, Wilhelm, \& Campbell, 2010)(Popova, 2017a)(Popova, 2017b). The Marcellus play is located between 3,000 and 6,500 feet below ground, while the Utica shale is located significantly lower at 7,000 to 12,000 feet below ground (Popova, 2017a)(Popova, 2017b). Both shale plays encompass much of Pennsylvania and West Virginia, while running into parts of eastern Ohio, western Maryland, and southern New York (Kargbo et al., 2010) (Figure 1). Pennsylvania, which lays in the heart of the Marcellus formation, was the second largest natural gas producing state in the nation in 2017 (U.S. Energy Information Administration, 2019d). Other states in the Appalachian basin such as New York and Maryland, have moratoriums on natural gas drilling (Hastings, Heller, \& Stephenson, 2017) (Sangaramoorthy, 2018)(Leff, 2015). 


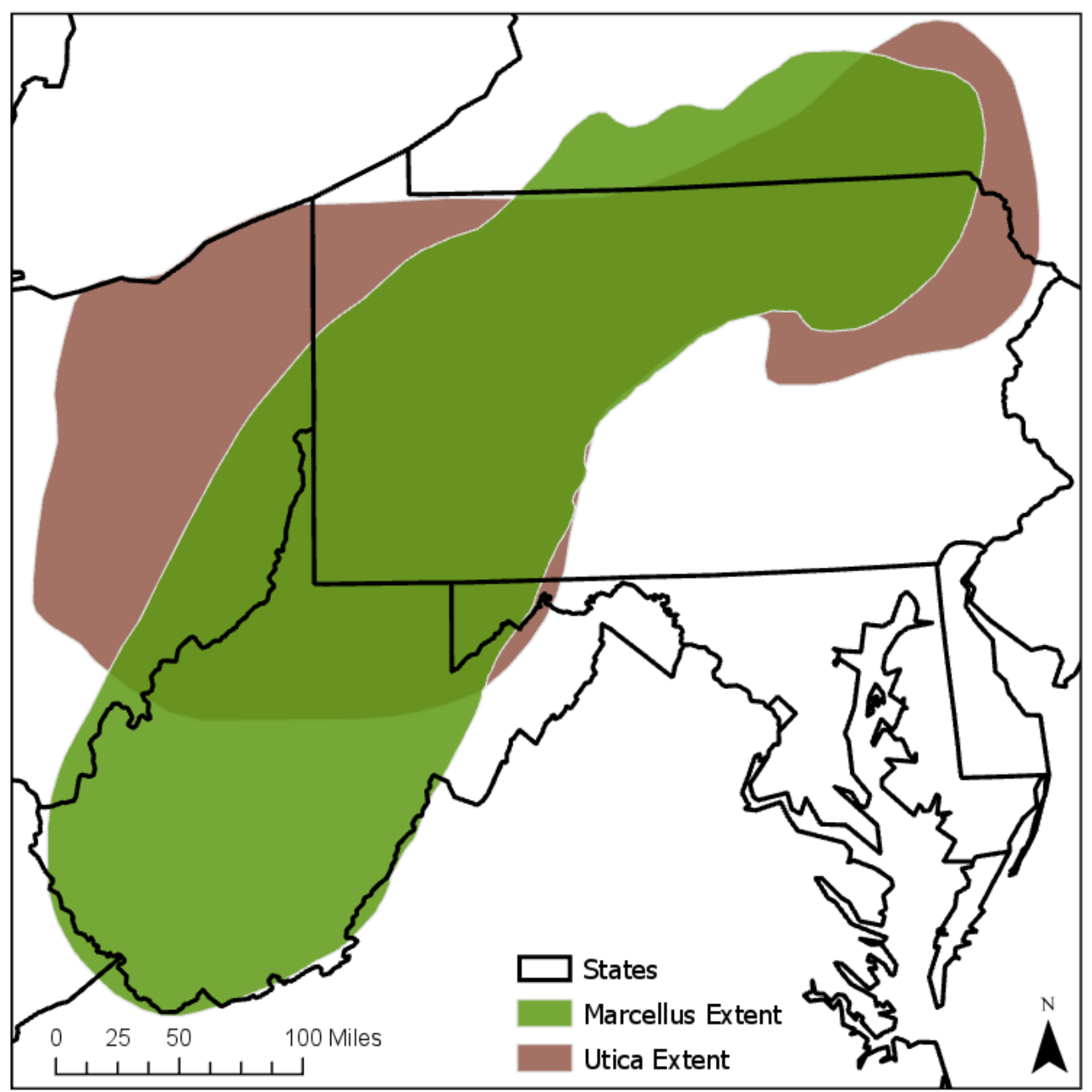

Figure 1: The Marcellus and Utica shale plays underlay much of the Appalachian basin (U.S. Energy Information Administration, 2016).

There are two types of wells that allow for the extraction of natural gas: conventional and unconventional wells (Figure 2). The Energy Information Administration (EIA) classifies conventional oil and gas production as "crude oil and natural gas that is produced by a well drilled into a geologic formation in which the reservoir and fluid characteristics permit the oil and natural gas to readily flow to the wellbore" (U.S. Energy Information Administration, 2019b). Conventional wells are buoyancy driven, and found in continuous gas accumulations with set boundaries, which means that they are more densely spaced than unconventional wells (Law \& Curtis, 2002) (Evans \& Kiesecker, 2014) (Song, Zhuo, Jiang, \& Hong, 2015). Unconventional wells are located in low permeability rocks, which require the tight sandstone to be fractured to retrieve the gas deposits (Song et al., 2015). Since unconventional wells do not have 
boundaries like the conventional wells, they drain a larger area, ergo producing more natural gas. Producing more gas per well means lower well pad density, but larger well pad area, pipeline diameter, and compressor station (The Nature Conservancy, 2014). Unconventional oil and gas (UOG) development in the Appalachian basin initiated in December 2004 when the company Range Resources started unconventional drilling in Pennsylvania with five total successful unconventional wells (Governor's Marcellus Shale Advisory Commission Report, 2011). Unconventional wells are drilled vertically until depths of 6,000 to 10,000 feet, then drilled horizontally along the shale layer which is then fracked to release the natural gas (Johnson et al., 2010).

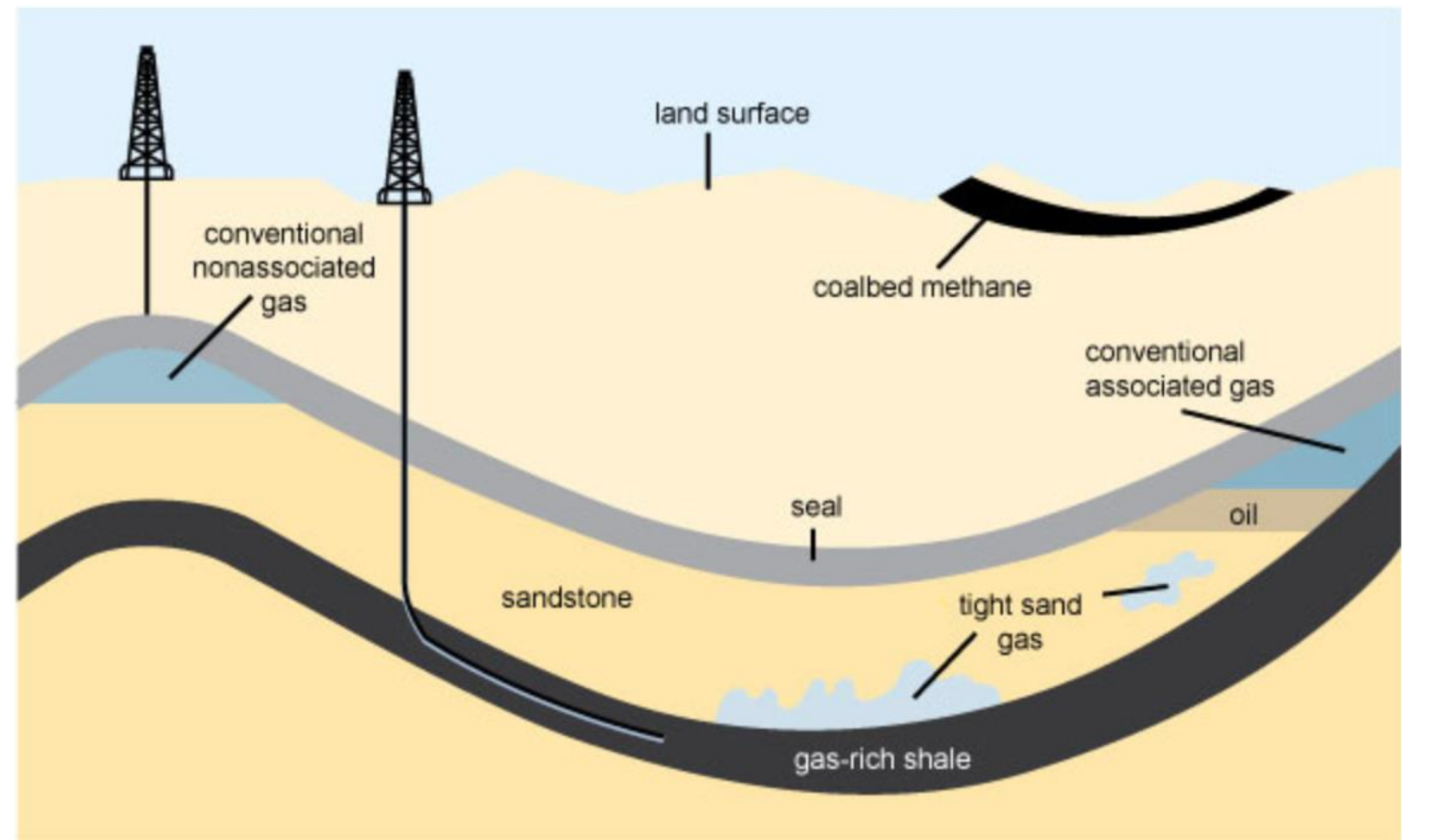

Figure 2: Conventional wells are typically drilled vertically, while unconventional wells are drilled both vertically and horizontally (U.S. Energy Information Administration, 2019c).

Hydraulic fracturing, also known as fracking, can be used both on conventional as well as unconventional wells. Fracking is a complex process that involves pumping proppants, usually sand or ceramic particles, and water into the well bore, which in turn fractures the rock formation (Armstrong et al., 1995). The proppants hold the fractures in the rock open, so that the petroleum products can flow more easily to the well. Conventional wells are occasionally fracked, as they mature, which opens the formation, and gives the well a longer lifespan (Norris, Turcotte, Moores, Brodsky, \& Rundle, 2016). Hydraulically fractured horizontal wells account for 
69 percent of all oil and natural gas wells drilled in the United States (Cook, Perrin, \& Van Wagener, 2018). Hydraulic fracturing is popular since it allows access to oil and gas reserves that are inaccessible to reach with conventional drilling methods (Boudet et al., 2014). In the period of initial growth, many companies permitted more wells than they could successfully drill to lay claim to the land and allow them to stay ahead of their competitors. The companies would drill on those sites to test productivity, and then move on to secure as many productive leases as possible (Johnson et al., 2010).

Conventional wells tend to have a smaller ecological footprint in comparison to unconventional wells. Preliminary data found by Zinkhan (2016), show that the average disturbance area of a conventional well is 0.66 hectares. The average unconventional well pad size can range from 1.2 to 2.8 hectares, but may have a total disturbance footprint of more than 12 hectares for a single pad (Johnson et al., 2010). Zinkhan (2016) found that the average unconventional well pad disturbance was 3.6 hectares in WV. An average unconventional well can produce oil across 80 to 170 acres, depending on lateral length (Johnson et al., 2010). Well laterals are placed in a northwest to southeast plane, so that they are perpendicular to the shale rock, which lays in a southwest to northeast fashion (WVDEP, 2020). The average conventional well pipeline is two to four inches, while an unconventional pipeline can be up to 24 inches in diameter respectively (Johnson et al., 2010).

Since there can be one to twenty wells on a single pad, UOG well pads tend to be larger than conventional oil and gas well pads. The pad must be large for unconventional development due to the equipment that must be able to maneuver around the pad to complete production, such as the drilling rig, stimulation equipment, and production appurtenances. Large roads must be built to each pad to support the large volumes of heavy duty truck traffic needed for the development of the well. Gathering lines are installed so the produced oil and gas can be transported to the nearest transmission lines. Disturbance related to UOG development is not related just to the well pad size alone. Disturbance also encompasses the well pad, roads, compressor stations and pipelines created.

Natural gas has proven to have more benefits than other commonly used fossil fuels for power generation. It produces half of the amount of carbon dioxide per unit of energy in comparison to coal (Kargbo et al., 2010), and uses less water per unit of energy than nuclear and coal fired power plants (Jackson et al., 2014). Other benefits of using natural gas as an energy source include reduced levels of sulfur dioxide $\left(\mathrm{SO}_{2}\right)$, nitrogen oxide $\left(\mathrm{NO}_{\mathrm{X}}\right)$, carbon 
monoxide (CO), and mercury $(\mathrm{Hg})$ in comparison to burning coal (Kargbo et al., 2010). Using natural gas for power generation does not produce billions of tons of toxic coal ash each year, and can help bridge the gap towards a renewable energy-based future (Jackson et al., 2014).

Even though natural gas is a cleaner source of energy than other fossil fuels, it still comes with its own costs. With the increase of well pads across the Marcellus region, forest fragmentation is becoming a widespread problem (Drohan, Brittingham, Bishop, \& Yoder, 2012) (Langlois, Drohan, \& Brittingham, 2017). Fragmentation leads to an increase in impervious surfaces, which in turn is a threat to quality of drinking water, stream health, and the integrity of headwater watersheds (Evans \& Kiesecker, 2014). Land cover change also impacts wildlife habitats and populations. Johnson et al. (2010) found that almost 40 percent of Pennsylvania's rare, threatened, and endangered species can be found in areas with high potential for Marcellus gas development.

As well sites are cleared and developed, research has shown that increased sediment flow into surface waters, and higher concentrations of total suspended solids (TSS) in water bodies is possible (Entrekin, Evans-White, Johnson, \& Hagenbuch, 2011). Higher sediment levels are known to have negative effects within lotic food webs (Entrekin et al., 2011). Olmstead, Muehlenbachs, Shih, Chu, \& Krupnick (2013) found in Pennsylvania that each additional 18 well pads resulted in a five percent increase in watershed level TSS concentrations. Drohan \& Brittingham (2012), indicated that erosion and sedimentation of surface waters is the most common problems of UOG development. A study by Williams, Havens, Banks, \& Wachal (2008) in Texas, found an increase in sedimentation of streams due to storm water runoff from well pads and other UOG development nearby.

As of 2012 in Pennsylvania, roughly 90 percent of the existing well pads were developed on private land (Drohan et al., 2012). With most wells occurring on private land, it is harder to manage land cover due to a lack of centralized decision making, and the variable lease negotiations for each separate landowner (Drohan et al., 2012). Mineral ownership characteristics also can affect land cover change. Landowners who own land and mineral rights have more of a say on what happens to the surface, than someone who only owns one or the other (Drohan et al., 2012). Currently, the Pennsylvania Department of Conservation and Natural Resources (PDCNR) policy is to place the shale-gas pads as close to existing roads as possible since roads are known to help contribute to the spread of invasive species, negatively affect wildlife and their habitat, and interrupt the movement of water across landscapes (Drohan 
et al., 2012). In a study about canopy removal and oil and gas development in the upper Susquehanna river basin, Young, Maloney, Slonecker, Milheim, \& Siripoonsup (2018) found that the volume of canopy removed for oil and gas related development was 60 percent of the volume of timber harvested from the State Forest lands.

With unconventional development, there is more to the disturbance of an ecosystem than the installation of the well pad alone. Drohan et al. (2012) classified drilling related land disturbance as any road development, pad installation, gathering lines, compressor stations, staging areas, or storage ponds. Wildlife habitat, especially core forest habitats, could be at risk for fragmentation and habitat loss in the future (Johnson et al., 2010)(Riitters et al., 2002). Habitat loss has a major effect on biodiversity, which many biologists believe that the pattern of habitat loss is more important than the quantity of habitat loss (Abrahams, Griffin, \& Matthews, 2015) (Johnson et al., 2010). Forest fragmentation leading to habitat loss can have immediate effects on wildlife populations, but the ecological response to fragmentation can vary due to affecting different species at different time scales (Makki, Fakheran, Moradi, Iravani, \& Senn, 2013). Edge effects can be detrimental to forest wildlife populations due to increased predation, changing lighting and humidity, and an increase in invasive species (Johnson et al., 2010) (The Nature Conservancy, 2014).

Potential impacts on land cover in the Appalachian region due to Marcellus shale production include increased impervious surfaces and deforestation from land clearing to construct well pads and associated infrastructure (Johnson et al., 2010). According to Evans \& Kiesecker (2014), new gas pads and wind turbines will drive between 268,503 and 495,357 acres of deforestation in the Marcellus shale play, at that level, there will be changed conditions at the sub watershed level.

Although well pads impact land cover, as time goes on it is possible to reduce land cover change. Most wells use a gathering line to transport the product from the well to a bigger, main distribution line. As the well pad density increases, it is possible that the infrastructure can be shared to an interstate or intrastate lines. Compressor and pigging stations can also share the right of ways, leading to reduced land cover change for infrastructure. Developing more wells per pad could also lead to a decline in land cover conversion, but an increase on other sources of disturbance such as noise pollution, or air quality degradation (Drohan et al., 2012). After the pad is constructed, the disturbed footprint becomes smaller, and when the well is done producing, the landscape must be returned to the original contour. 
As natural gas continues to be used as an energy source, it is important to determine the effects that it is having across the landscape. There are relatively few studies looking at potential surface land cover characteristics of future Marcellus UOG development. Like any resource, it must be managed appropriately to minimize its impact on the environment, while also maximizing longevity.

\section{Objectives}

1. Assess current level of unconventional well development in the Appalachian basin.

2. Compare and contrast the site disturbance related to unconventional development in Pennsylvania, West Virginia, and Ohio.

3. Evaluate land cover types in areas disturbed by UOG development before and after site construction.

4. Evaluate potential surface land characteristics of future UOG development in the Appalachian basin

\section{Methods}

\section{Unconventional Development in the Appalachian Basin}

\section{UOG Well Data}

The focus of this project is on unconventional gas wells and associated land cover in Pennsylvania, West Virginia, and Ohio in the Appalachian Basin from 2007 to 2017. Data for each state were acquired through the respective regulatory agency. Each state agency is responsible for handling the permits associated with development. Pennsylvania and West Virginia well permits are regulated by each states Department of Environmental Protection (DEP), while Ohio permits are regulated by the Ohio Department of Natural Resources (ODNR). Federal agencies are mainly responsible for the transportation, storage, refining, and marketing of the product (PHMSA, 2019). They also handle permitting under the Clean Water Act (Clean Water Act, 1972) and Endangered Species Act (Endangered Species Act, 1973).

Because each state has a different agency responsible for permitting the wells, each database was unique and included a variety of data fields. In Pennsylvania, the oil and gas 
exploration is regulated by the Oil and Gas Act, Coal and Gas Resource Coordination Act, and Oil and Gas Conservation Law. The Pennsylvania Department of Environmental Protection (PADEP) is responsible for the permitting of the proposed oil and gas wells. Pennsylvania data obtained from the DEP reports include: well location, permit issue date, operator name and address, authorization type, API number, configuration, well type, farm name, and spud date.

Well permits for West Virginia were extracted from the West Virginia Department of Environmental Protection (WVDEP) Oil \& Gas database. According to the Natural Gas Horizontal Well Control Act, any permitting of WV gas wells must be done through the WVDEP (Horizontal Well Act, 2011). After the WVDEP has assessed the permit, it is then catalogued into a database by the West Virginia Geological and Economic Survey (WVGES). In the West Virginia Oil \& Gas database, the following information was associated with the permitted wells: API number, permit number, permit type, well type, well use, current operator, surface owner, well number, permit activity type, activity date, UTM locational data, well pad name, and the target formation.

In Ohio, the Ohio Department of Natural Resources, Division of Oil and Gas Resources Management (ODNR-DOGRM) is responsible for regulating the oil and natural gas wells. Under Chapter 1509 of the Ohio Revised Code (ORC) and Chapter 1501 of the Ohio Administrative Code (OAC), the ODNR-DOGRM is responsible for regulating the location, construction, design, spacing and operation of the oil and gas wells in the state. The ODNR-DOGRM is also responsible for the permitting of the wells, and creating the database which catalogues all the important data about the well. The Ohio well database includes all the categorical data about the well including: API number, date issued, well name, number, location, depth, well class, formation, purpose, elevation, operator name, number, address, acreage, and permit issue date.

Since drilling takes place horizontally on an individual UOG well, multiple wells can be placed on a single well pad. Each well pad must adhere to best management practices assigned by the state. Best management practices (BMPs) are set to protect the environment from excess degradation from resources of interest. UOG development across the Appalachian basin are subject to BMPs, just like any other environmental industry is. Ohio, Pennsylvania, and West Virginia all have different best management practices, and are each regulated through a different state regulatory agency. West Virginia defines a horizontal well as "any well site, other than a coalbed methane well, drilled using a horizontal drilling method, and which disturbs 
three acres or more of surface, excluding pipelines, gathering lines and roads, or utilizes more than two hundred ten thousand gallons of water in any thirty day period" (Horizontal Well Act, 2011).

There are many types of BMPs regarding oil and gas production across the Appalachian basin. The majority of BMPs cover the topics of air quality, human health, land-disturbance impacts, soil, vegetation, water quality and quantity, and wildlife (Bearer et al., 2012). There are two forms of BMPs enforced in Pennsylvania. Passed in 2012, Act 13 provides updated regulations that encompass UOG drilling across the state (Pa General Assembly, 2012). Well pad development is also regulated under the Clean Streams Law in Pennsylvania, enforced by the Department of Environmental Protection (The Clean Streams Law, 2006). All best management practices for the state of West Virginia, are outlined in the West Virginia Erosion and Sediment Control Field Manual (WV DEP, 2012). In Ohio, the regulation of BMP's is done through the ODNR-DOGRM Regulatory enforcement program under the Ohio Administrative Code 1501:9 (Ohio Administrative Code, 2019). The two types of BMPs focused on in the state are water sampling, and well pad construction. BMPs help to ensure reduced impacts on the environment, while still allowing the natural resource to be extracted.

\section{UOG Surface Characteristics}

Locational data from each permitted well site, gathered from each state's regulatory agency, were combined into Environmental Systems Research Institute (ESRI)'s ArcGIS software (version 10.6) for further analysis. To determine whether construction had begun on the well sites, locational information was analyzed with respect to current aerial imagery for each state. National Agriculture Imagery Program (NAIP) aerial imagery was used for all states. Horizontal wells that showed no signs of activity were excluded from the study. Those wells that showed disturbance in NAIP imagery were considered for subsequent analyses.

NAIP imagery is developed by the United States Department of Agriculture (USDA) Farm Service Agency during the agricultural growing season in the continental United States. Unlike satellite imagery, it is attained from aerial photography and is available to be used by the public free of charge, with a scale of 1:10,000. NAIP imagery was chosen for the study due to its availability and high resolution. NAIP imagery resolution varies depending on year, and state. It has ranged from 2-meter resolution in the beginning to 60 -centimeter resolution in 2018 . The imagery used in the study, was acquired at a one meter ground sample distance, which 
provided the most up to date imagery that was easily accessible for all three states. With the 1 meter resolution of the imagery, the minimum mapping unit was 9 square meters, which is the smallest land cover size that could be delineated in the study. Imagery was obtained through each states regulatory agency. Pennsylvania imagery was acquired through the Pennsylvania Spatial Data Access, West Virginia imagery was attained through the West Virginia GIS Technical Center, and Ohio imagery was retrieved from the USDA Geospatial Data Gateway.

The spatial data acquired from each state's well permits were visually inspected in ArcGIS using the NAIP imagery. Using the most recent imagery at a scale of $1: 10,000$, the permitted well locations were inspected for any signs of activity including dirt moved, forest clearings, roadways, or an already constructed well pad. Older imagery was used to confirm sites where activity level was difficult to determine. By comparing multiple imagery years, the true extent of development was determined. Due to the variability of NAIP imagery, different years of imagery were used for different states (Table 1). Ohio and Pennsylvania's most recent NAIP imagery taken was in 2017. West Virginia's most recent NAIP imagery was taken in 2016. Wells that showed signs of activity during each states most recent imagery, were used in the study.

Table 1: Years of NAIP imagery utilized in the analysis.

\begin{tabular}{ll} 
State & NAIP Imagery Year \\
\hline Ohio & 2009,2017 \\
Pennsylvania & $2008,2013,2015,2017$ \\
West Virginia & $2007,2009,2011,2014,2016$
\end{tabular}

The variability in NAIP imagery comes from the available funding, the Farm Service Agency (FSA) acquisition cycle by state, and the time of year the imagery is taken. Starting in 2009 , the NAIP switched from a five-year, to a three-year acquisition period. Even though the most recent imagery was used to determine well activity, there were still limitations to it. Since NAIP imagery is taken during the leaf-on period of the year, well activity had the potential to be missed during the final few months of the calendar year, after the imagery was taken for that year. Since West Virginia imagery was taken in 2016, it did not show the activity that occurred during the 2017 calendar year. Although most of the land cover types remain the same throughout the growing season, they will visually change depending on when the imagery was taken. Trees and grass look different as the growing season progresses. Early in the growing season, both land covers are a deep dark green, and can be difficult to distinguish apart. As the 
growing season progresses, it is easier to tell the two land covers apart, as the trees stay a dark green, and the grass becomes a lighter green. Since NAIP imagery is collected every other year, and has a pixel size of one meter, not all UOG well pad disturbance was recognizable. With those limitations, it is possible that disturbed sites were excluded from the study, due to the disturbance footprint being too small. A few of the images used in the study were acquired in the early fall of the year, when the leaves of trees were starting to change colors. Shadows, and clouds in the imagery were other limitations to using NAIP. Using four band (red, green, blue, NIR) NAIP, is known to produce increased accuracy over the three band imagery (Franklin, 2018). To keep all classifications consistent, only three band NAIP was used for the classification, largely because the four-band imagery was not available during the predevelopment imagery.

After acquisition, NAIP imagery is required to be sent to the Aerial Photography Field Office (APFO) within 30 days after flying and collecting the imagery. The APFO must then inspect the imagery for errors, and make it available within a year. Once all images within a project area (state) are accepted, they are released to the public. Due to this, 2018 West Virginia NAIP imagery was not available in time to use for the project. Since it is not possible to collect all the imagery for an entire state in one day, the NAIP imagery, must be combined to create a Digital Orthophoto Quarter Quad (DOQQ). A DOQQ is a digital image of an aerial photograph, which combines the photo with the geometric qualities of a map. Orthophotos are imagery that is corrected for elevation, which allows accurate measurements to be made from them. Each state is covered by thousands of DOQQ's, which each measure 3.75-minutes of latitude by 3.75-minutes of longitude, and are in the Universal Transverse Mercator Projection (UTM), on the North American Datum of 1983 (NAD83). Due to time constraints of the study, it was not feasible to mosaic the uncompressed DOQQ files across all three states. Instead, Compressed County Mosaics (CCM) were used in the study, which are created by joining all the DOQQ images into a single mosaic for a certain county. The CCMs were used for data analyses, due to their accessibility, and size.

Many types of imagery have been assessed to determine the land cover characteristics of UOG development. Langlois (et al. 2017) used aerial imagery flown in leaf off conditions to asses habitat conversion and forest fragmentation. Drohan (et al. 2012), Jantz (et al. 2014), Slonecker (Milheim, Roig-Silva, \& Fisher, 2012), and Slonecker (Milheim, Roig-Silva, Malizia, et al., 2012) used NAIP imagery to digitize the disturbance associated with UOG development. 
NAIP imagery is largely used because it is updated frequently (2-3 years), has high resolution (1 meter), and is available for the continental United States.

\section{Land Cover Characteristics Associated with UOG Development}

\section{Supervised Classification}

Once it had been determined which well pads had shown signs of development, a 25hectare circular buffer was placed around each well on the well pad. Johnson et al. (2010) found that an average unconventional well pad and associated infrastructure in the Marcellus region occupied 9 acres per well pad. Similarly, Evans \& Kiesecker (2014) and Arthur \& Cornue (2010) found that the same wells and associated infrastructure occupied 11.6 and 7.4 acres respectively. Previous studies have used 15 and 20-hectare buffer sizes to assess UOG development (Zinkhan Jr, 2016). Upon inspection, some UOG infrastructure was not captured within that area, so an increased buffer size of 25-hectares was chosen to ensure that all disturbance associated with the development was accounted for. With an average spacing of 40 to 160 acres per well in the Marcellus region, a few buffers overlapped (U.S. Department of Energy, 2009). The shared boundaries were dissolved for those buffers that overlapped. Once the buffer was created and dissolved, the NAIP imagery was clipped to the 25-hectare buffers. The buffers in each state were then assigned an identification number, to better track the changes.

There are many ways to investigate land use change from aerial imagery. One of which, is to use a supervised classification approach. The most time-consuming step in the classification process is training the dataset (Olofsson et al., 2014). In this study, training data had to be utilized to acquire the spectral properties of each land cover class. By using five training samples per land cover class, it is possible that not all spectral classes were represented equally in the training data set. The digitizing of the polygons used to train the data have the potential to overestimate the class variance. The maximum likelihood classifier used to classify the imagery, relies heavily on normally distributed signatures. In a few counties, there was a large diversity in the spectral classes of the land cover which did not have normally distributed signatures. 
Another approach to land use change classification is by digitizing the extent of disturbance associated with UOG development (Drohan et al., 2012; Jantz et al., 2014; Johnson et al., 2010; Langlois et al., 2017; Slonecker, Milheim, Roig-Silva, \& Fisher, 2012; Slonecker, Milheim, Roig-Silva, Malizia, et al., 2012). Digitization of UOG development, is time consuming, and can easily contain errors due to digitizer bias. In other studies that have used digitization to assess the level of disturbance, a sampling approach was used instead of a census. The supervised classification methodology used in this study removes the digitizer bias, and allowed for the inclusion of all well pads in the entire Appalachian basin to be included in the study. With more time, it would be possible to capture the exact extent of disturbance across the entire Appalachian basin using a digitized approach. Using three land cover classes, it was easy to determine where, and to what extent the land cover changed throughout the region.

A subset of known pixels in an image were selected and then classified to a given land cover and were used as training data. The training areas were digitized to ensure they were dispersed throughout the study area, and were as spectrally distinct as possible. Spectral signatures were then created from the training data, to be used as an input source in the maximum likelihood classifier. The spectral reflectance properties of the training data, were used to help classify the imagery used in the study.

A supervised classification approach was chosen over other classification options such as an object based classifier, and an unsupervised classification. Object based classification uses spatial and spectral properties to identify objects, which can be different land cover types (Myint, Gober, Brazel, Grossman-Clarke, \& Weng, 2011). The main difference between a supervised and unsupervised classification is the timing of the observer in the process. An unsupervised classification classifies the image without training data, and places like pixels into groups. The observer must then identify the different groups, assign labels, and make sure they are correct to give the data meaning, which can be time consuming. Due to the additional software needed for an object based classification, and the additional time needed for unsupervised classification, the supervised classification approach was used in this study.

The three main land cover types the study focused on were grass, forest, and impervious surfaces, such as roads and well pads. Only three classes were used to classify the landcover because the study mainly focused on the natural versus unnatural properties of the land. Representative samples were collected across the entire CCM, allowing different spectral properties of the same class to be established. Five representative samples from each land 
cover class were used to make a training data set to classify the imagery. Each individual class contained between 1,000 and 3,000 pixels to be used as the training data. Spectral signatures were then created based on the training data. Since the imagery was so variable, and was gathered at different times of the year for each county, a training data set was required for every individual CCM. Training data was collected not only for each county in the study, but also for the pre-development, and post-development imagery as well.

There were a few limitations to training a different data set for each image that was classified throughout the study. Classifying imagery on a county basis proved to be difficult, as a few counties only contained one well pad. Due to the resolution of the imagery used, sometimes it was not possible to identify all three land cover types in a CCM. With only five training data samples per land cover class, it is possible that there were unique spectral classes of grass and forest, that were not identified correctly. Even though the training data samples were selected at random, it is possible that there may be bias in the data used, since each shape is of different size, and location. The forest and grass land cover types shared similar spectral properties due to the variance in the imagery used. Sharing similar spectral properties depending on season, location, and land usage proved to be another limitation for using the supervised image classification approach.

The maximum likelihood classification tool was used to classify the land cover using the NAIP imagery, within the 25-hectare well pad buffer (Figure 3). The tool used an algorithm to assign imagery pixels a classification based on the class mean, and co-variance from the user created training data as seen in Figure 4. The classification is probability based, and each pixel in the image receives the classification of the highest probability land cover class. Since the study was focused on looking at the differences in land cover between pre and postdevelopment, there were no issues classifying impermeable surfaces such as rock, concrete, and asphalt as well pad disturbance. Due to the size of the imagery files, each county was classified individually. After the imagery was classified, a majority filter was used to replace some of the cells in the raster, based on the majority of the neighboring cells. The majority filter tool reduced the number of isolated cells in the classification, making for a cleaner image. After the majority filter produced a raster, the data was extracted for each well pad across the three states, and placed into excel for subsequent analysis. 


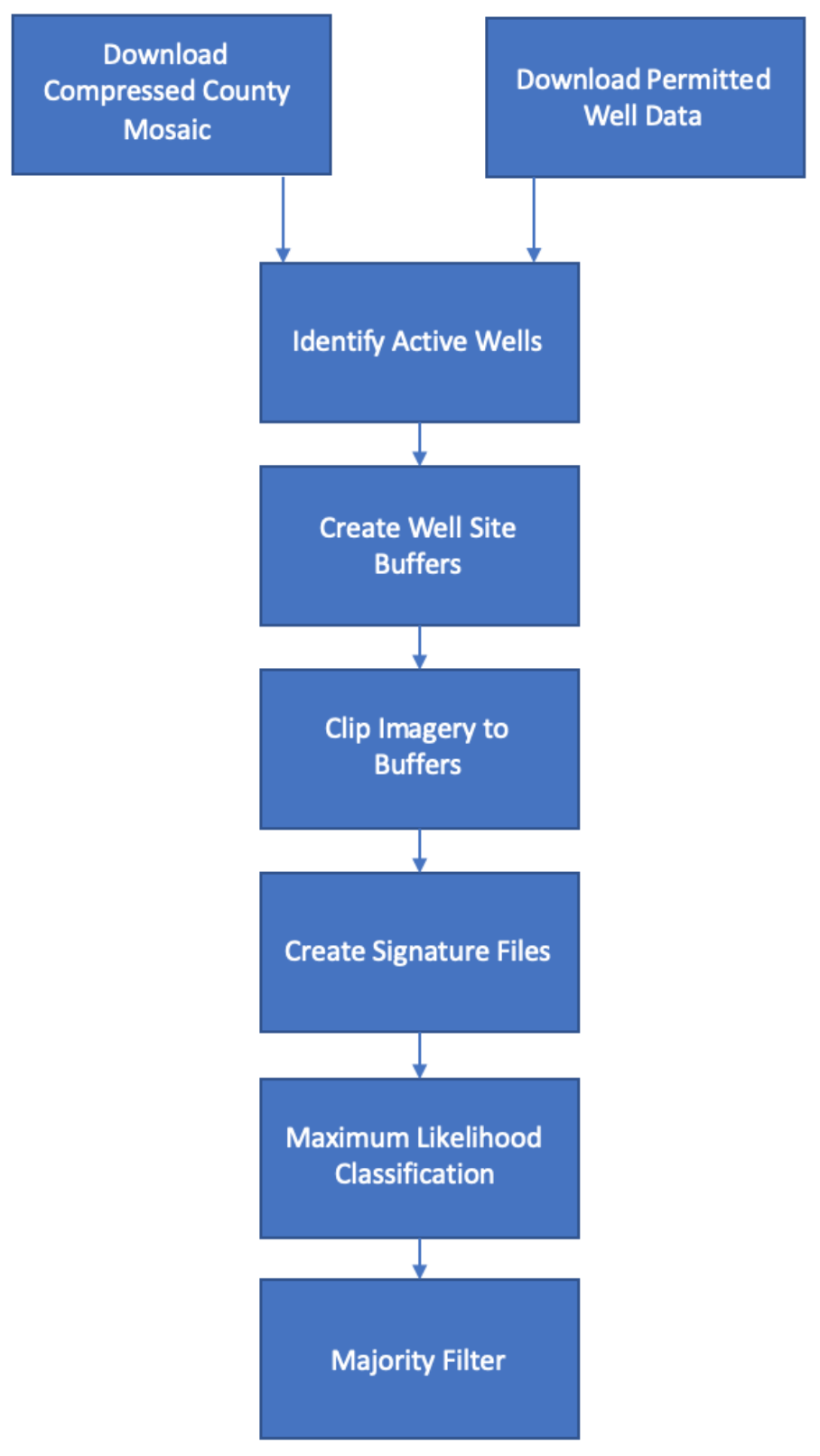

Figure 3: The flowchart of the steps taken to determine land cover on well sites throughout the study area.

\section{Accuracy Assessment}

Training data were collected at a county level to improve accuracy in the classification of the pre and post-development imagery. Classification accuracy was determined using an equalized stratified random sample approach. Thirty random points were assigned to each of the three land cover classes identified in the study: forest, impervious surfaces, and grass. Each 
random point was used as ground reference data to compare the accuracy of the classified map with the type of landcover that occurred at the random point. The term ground reference data is used instead of ground truth, because there is still a slight chance of error in the data. The original training data was not utilized in the accuracy assessment, because it would provide a biased higher accuracy for the classified map (Olofsson et al., 2014). A confusion matrix (Strager, 2008) (Olofsson, Foody, Stehman, \& Woodcock, 2012) was then created to ascertain the success of the image classification (Table 2).

The total accuracy of the classification was found by adding all cells that were identified correctly together, and then dividing them by the total cell count of correct and misidentified cells. Although total accuracy gives the percentage of correctly identified plots, it is an average, and does not give any information on the distribution of the error between classes. Errors of omission and commission are related to the user's and producer's accuracy, which help to further analyze the accuracy of the image classification. User's accuracy describes how often the class identified will be present on the ground, while producer's accuracy describes how often on the ground classes are identified correctly (Olofsson et al., 2012) (Olofsson et al., 2014). User's accuracy is calculated by 1-commission error, while producer's accuracy is calculated by 1 -omission error.

Table 2: Accuracy assessment of the supervised classification for the post-development time, using 2017 NAIP imagery, for Ohio. Reference numbers represent the ground reference data, while the map numbers represent the classification of each image pixel.

\begin{tabular}{|c|c|c|c|c|c|}
\hline \multirow[b]{2}{*}{ Map } & \multicolumn{3}{|c|}{ Reference } & \multirow{2}{*}{$\begin{array}{l}\text { Row } \\
\text { Total }\end{array}$} & \multirow{2}{*}{$\begin{array}{l}\text { User's } \\
\text { accuracy }\end{array}$} \\
\hline & Well & Grass & Forest & & \\
\hline Well & 29 & 0 & 0 & 29 & 100 \\
\hline Grass & 1 & 21 & 1 & 23 & 91 \\
\hline Forest & 0 & 9 & 29 & 28 & 76 \\
\hline Column Total & 30 & 30 & 30 & 90 & \\
\hline Producer's & 97 & 70 & 97 & & \\
\hline
\end{tabular}




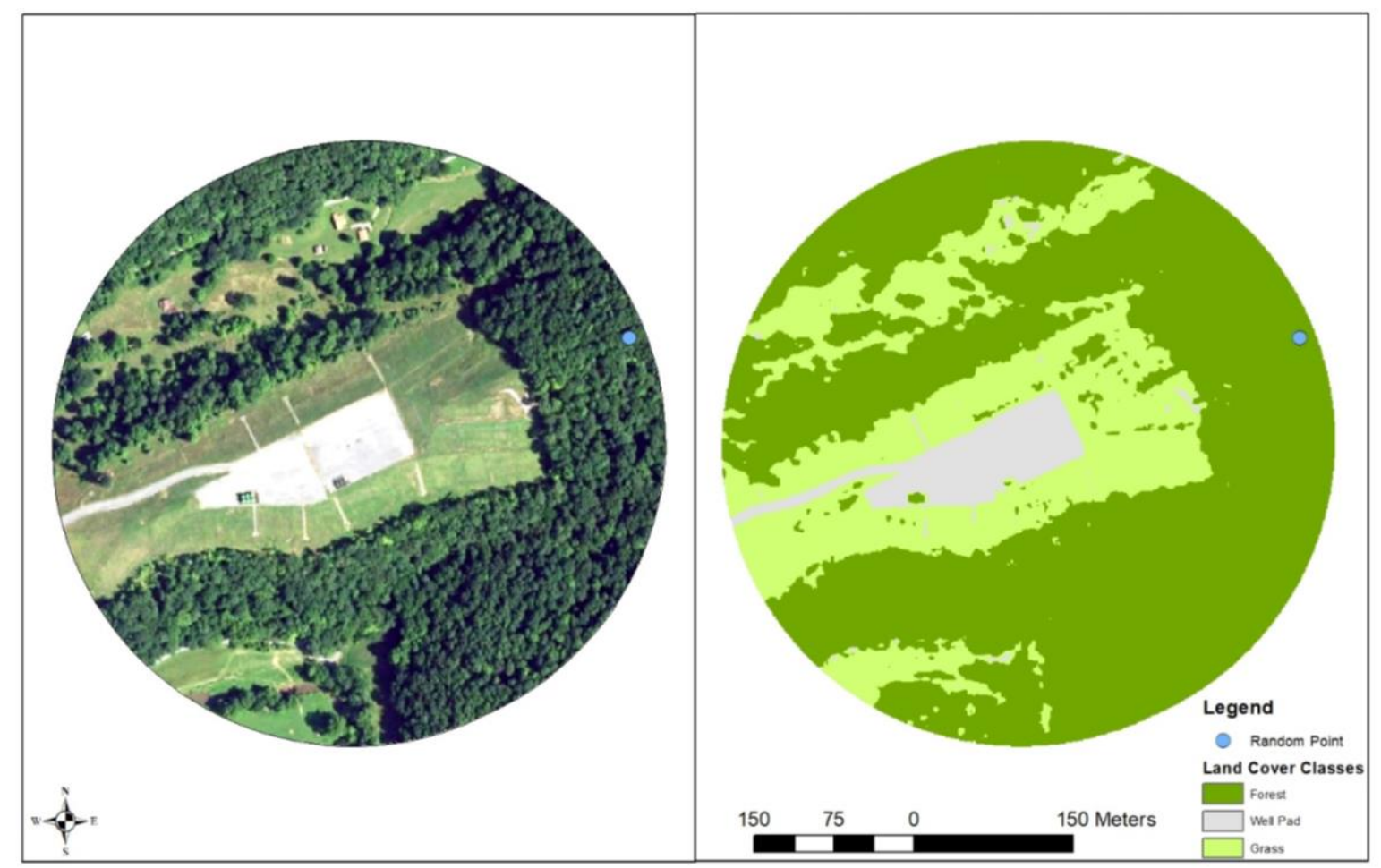

Figure 4: NAIP imagery from 2017 and supervised classification results from an unconventional well pad in West Virginia. Imagery was classified into forest, grass, and impervious surface using the maximum likelihood classifier tool within ArcGIS.

\section{Land Cover Change}

Following classification for the pre and post time periods, the area of each land cover change was calculated. Using the raster calculator function within ArcMap, the pre and postdevelopment raster's were summed to produce an output with nine values (ESRI, 2019). Each value in the output described a land cover change for each individual cell in the raster (Table 3). The change categories that were focused on for the remainder of the study and would fully capture changes due to unconventional development included forest to impervious surface, grass to impervious surface, and forest to grass. The remaining changes in classification were not used in the study, because they represented erroneous classifications or did not directly relate to unconventional development. 
Table 3: Nine potential types of land cover change in the Appalachian basin between 2007 and 2017.

\begin{tabular}{ll}
\hline Pre-Land Cover & Post-Land Cover \\
\hline Forest & Forest \\
Impervious Surface & Forest \\
Grass & Forest \\
Forest & Impervious Surface \\
Impervious Surface & Impervious Surface \\
Grass & Impervious Surface \\
Forest & Grass \\
Impervious Surface & Grass \\
Grass & Grass \\
\hline
\end{tabular}

The importance of land cover changes associated with unconventional development, were investigated among states. Data analyses were performed with SAS /STAT Software of the SAS System for Windows, Version 9.4, Copyright (C) 2016 by SAS Institute Inc., Cary, NC, USA. The GLIMMIX procedure was used to model differences in land cover change (ha) among states and land cover type before and after unconventional development. The null hypothesis is that there is no difference in land cover change (ha) among states and land cover types before and after unconventional development. The alternate hypothesis is that there is a difference in land cover change (ha) among states and land cover types before and after unconventional development. The model was defined as:

$$
Y_{i j k l}=\mu+\alpha_{i}+\emptyset_{j}+\gamma_{k}+\alpha \emptyset_{(i j)}+\partial_{l(i)}+\varepsilon_{(i j k l)}
$$

where $Y_{i j k l}$ is the change in pre/post land classification (ha), $\mu$ is the overall mean, $\alpha_{i}$ is the fixed effect of state, $\emptyset_{j}$ is the fixed effect of land change type (forest to impervious, forest to grass, grass to impervious), $\gamma_{k}$ is the fixed effect of pre-forest cover (\%) as a covariate, $\alpha \emptyset_{(i j)}$ is the interaction between state and land change type, $\partial_{l(i)}$ is the random effect of well pads within a state, and $\varepsilon_{(i j k l)}$ is the full model error. Pre/post land change was log transformed before all analyses. Subsequent pairwise comparisons of treatments showing significant differences were made with Tukey-Kramer adjustment for multiple comparisons. All statistical comparisons were made at the 0.05 significance level. 


\section{Pre and Future Development Land Cover Characteristics}

\section{Pre-Development Site Characteristics}

To determine if there were any preferential land cover characteristics when locating an unconventional pad, land cover was assessed at known well locations prior to unconventional development and at random locations within the study area. Random land cover samples were located within one county of each state where the greatest number of completed unconventional pads were observed. This included Bradford county in Pennsylvania, Doddridge county in West Virginia, and Belmont county in Ohio. Thirty random 25-hectare buffers were placed in each of the chosen counties, with no additional restrictions on their location. NAIP imagery from 2007 was used to classify the random buffers in each of the counties. The same supervised classification methodology was used to determine the land cover breakdown within the random buffers. Once the imagery was clipped to the random buffers, the training data that was collected for the pre-development imagery was used as the classification dataset. The majority filter tool was then used to replace cells in the raster based on the majority of the neighboring cells. The GLIMMIX procedure was used to model differences in land cover (ha) among known unconventional sites and random buffers within each of the highest well-density counties. The null hypothesis was that there is no difference in land cover among known unconventional well sites and random buffers. The alternate hypothesis is that there is a difference in land cover among known unconventional well sites and random buffers. The model was defined as:

$$
Y_{i j k l}=\mu+\alpha_{i}+\emptyset_{j}+\gamma_{k}+\partial_{l(i)}+\varepsilon_{(i j k l)}
$$

where $Y_{i j k l}$ is the percent classification of forest, grass, and impervious cover, $\mu$ is the overall mean, $\alpha_{i}$ is the fixed effect of location (either known unconventional development or random buffer), $\emptyset_{j}$ is the fixed effect of state, $\alpha \emptyset_{(i j)}$ is the interaction between location and state, $\partial_{l(i)}$ is the random effect of counties within a state, and $\varepsilon_{(i j k l)}$ is the full model error. Known and random location land cover classifications were log transformed before all analyses. Subsequent pairwise comparisons of treatments showing significant differences were made with Tukey-Kramer adjustment for multiple comparisons. All statistical comparisons were made at the 0.05 significance level. 


\section{Future Development Characteristics}

Once a well pad is drilled, completed, and ready to be produced, operators file a declaration of pooled unitization (DPU) for the producing location in the county records where the well is located. The DPU describes the producing unit including the operator, the lease characteristics, total land area that is producing, the landowners that own the mineral resources in the unit, and the percentage ownership for each owner. The DPU typically contains those acres that are being produced by the well bore that has been unitized. DPUs can be as low as 80 acres to as high as several thousand acres. Their size is determined by the number of wells included and the length of the lateral proportion of the well bore. The land area associated with the unit is highly variable and can be amended by the operator over time. Since the DPU is the area that a certain well pad is theoretically producing oil and natural gas from, no additional wells should be permitted or located in the same area. To assess trends in future development, a hypothetical DPU buffer was created over each permitted unconventional well in the study area. A DPU buffer was built in the northwesterly to southeasterly direction to follow the drilling pattern commonly used during unconventional development in the Appalachian basin (Figure 5) (WVDEP, 2020).

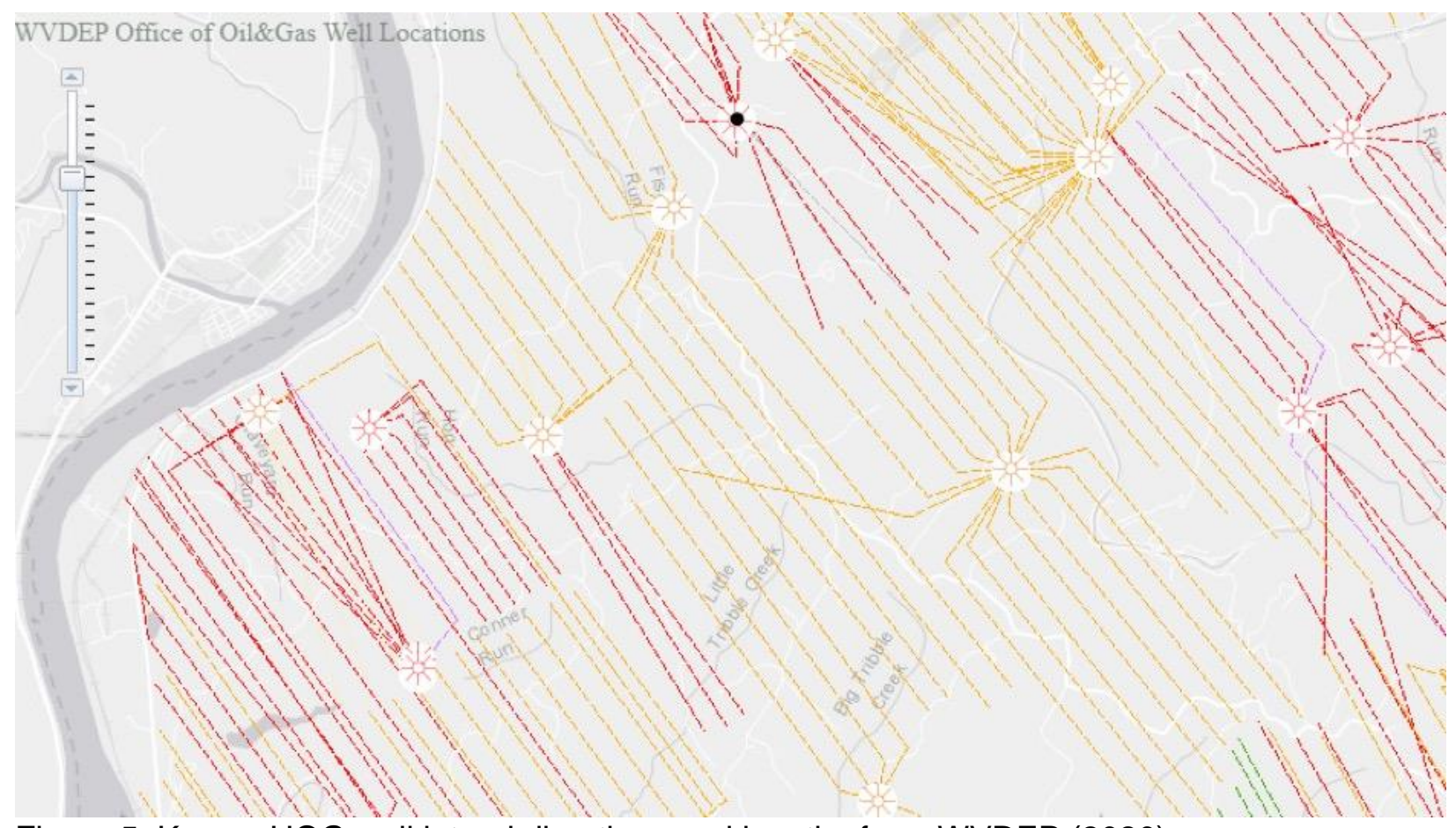

Figure 5: Known UOG well lateral directions and lengths from WVDEP (2020). 
The hypothetical DPU buffers displayed the areas of the Appalachian basin that have been developed, and those areas that are currently undeveloped. Using the top three counties in each state that had the highest number of horizontal wells, 25-hectare random circular buffers were randomly placed in the undeveloped areas of Bradford county, Pennsylvania, Doddridge county, West Virginia, and Belmont county, Ohio. Using the same supervised classification methodology, the post-development training data were used for each county to classify the undeveloped buffers. Understanding the land cover characteristics associated with the undeveloped areas will offer insight to potential future impacts due to UOG development in the selected counties.

\section{Results}

\section{Unconventional Development in the Appalachian Basin}

During the study period, 25,771 horizontal wells were permitted across Pennsylvania, West Virginia, and Ohio (Figure 6). Of the 25,771 well permits in the region, a total of 21,997 wells showed signs of surface activity as of the latest imagery available in each state. The 21,997 active wells, were located on a total of 4,212 well pad buffers across the study region.

Pennsylvania had the greatest number of bore locations with 17,609 horizontal wells permitted within the state during the study period. Of the 17,609 permits in Pennsylvania, 15,474 showed signs of surface disturbance according to 2017 NAIP imagery. In West Virginia, 5,294 horizontal wells were permitted between 2007 and 2017. A total of 3,874 of the 5,294 permitted wells showed signs of surface activity. In Ohio, 2,649 of the 2,868 total permitted wells showed signs of activity in the most recent 2017 NAIP imagery. The 15,474 active wells in Pennsylvania, were located on a total of 2,741 well pad buffers. West Virginia contained a total of 780 well pad buffers, followed by Ohio, which contained a total of 691 well pad buffers respectively.

The average wells per pad across the Appalachian basin is 5.2. Pennsylvania has the highest ratio, with an average of 5.6 active wells per pad, respectively. West Virginia contains an average of 5 wells per pad, while Ohio has an average of 3.8 wells per pad.

Almost fifty percent of all active wells in Pennsylvania were in either Bradford, Washington, or Susquehanna counties. Bradford county contained 2,965 active wells, 
Washington county had 2,225 active wells, and Susquehanna county contained a total of 2,152 horizontal active wells. There were 2,741 25-hectare buffers across thirty-seven different counties in Pennsylvania. Ten of the thirty-seven counties in Pennsylvania contained less than 10 well pad buffers. Bradford and Susquehanna counties contained the most well pads per county in the state with 541 and 394 well pad buffers respectively. In West Virginia, Doddridge, Wetzel, and Marshall counties contained over forty percent of all the active wells across the entire state. Doddridge county had 661 active wells, Wetzel county contained a total of 516 wells, and Marshall county contained 497 active wells as of 2017. West Virginia contained a total of 780 well buffers across the state. Twenty-one of the thirty-eight counties in the state contained less than 10 well pad buffers. The two counties in West Virginia that contained the most well pads were Marshall, and Doddridge county. Marshall county had a total of 98 well pad buffers, while Doddridge county contained a total of 96 well pad buffers. Seventy percent of all active wells in Ohio occurred in four counties in the eastern part of the state. Carroll and Belmont counties both contained 524 active wells. There were 405 active wells located within Harrison county, followed by 398 active wells located in Monroe county. In Ohio, 691 well pad buffers were found in twenty-seven different counties across the state. Of the twenty-seven counties in Ohio that contained at least one well pad buffer, sixteen counties contained less than 10 buffers. Belmont and Carroll counties had the most well pad buffers at 123, and 122 buffers respectively.

The top four counties that have the highest well density, all occur in Pennsylvania. Bradford, Greene, Susquehanna, and Washington counties all have an average well density of 2.6 wells per square mile. Doddridge county, West Virginia has an average of 2 wells per square mile, while Carroll county, Ohio had an average well density of 1.31 wells per square mile. Greene county, Pennsylvania also has the largest average well pad density of 0.77 well pads per square mile. Bradford and Susquehanna counties, Pennsylvania both had a well pad density of 0.47 well pads per square mile. 


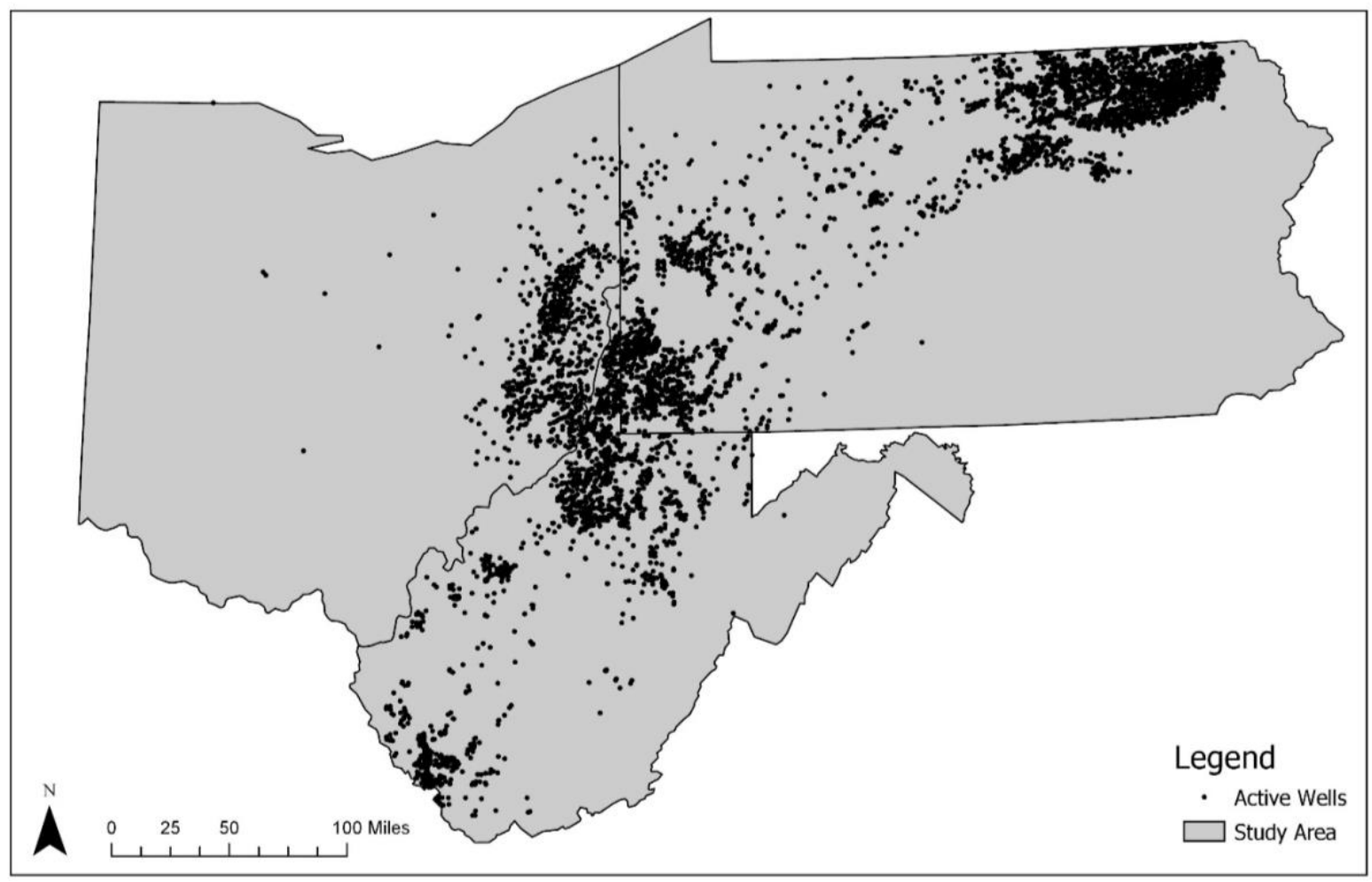

Figure 6: The geographical location of all active wells, which were used in the study

\section{Land Cover Characteristics Associated with UOG Development}

\section{Accuracy Assessment}

Total accuracies on the classification of the land cover for each of the states in the study area were high. Overall classification accuracy was $88 \%$ for 2007 and $89 \%$ for 2017 . West Virginia classification was the highest at 91\% and 94\% total accuracy for 2007 and 2016 imagery respectively. Likewise, Pennsylvania image classification produced $79 \%$ and $84 \%$ total accuracies based on 2008 and 2017 imagery. Ohio image classification produced $92 \%$ and 88\% total accuracies based on 2009 and 2017 imagery.

Producer's accuracies of 100 percent were found in the forest category of the post West Virginia development, and the impervious category in the pre Ohio development. The lowest producer's accuracy was in the pre-development impervious category of West Virginia at 33 percent (Table 4). Producer's accuracies for Pennsylvania were between 75 and 95 percent respectively. 
Table 4: Accuracy assessment of the supervised classification for the pre-development time, using 2007 NAIP imagery, for West Virginia. Reference numbers represent the ground reference data, while the map numbers represent the classification of each image pixel.

\begin{tabular}{llllll}
\hline \multirow{2}{*}{ Map } & \multicolumn{5}{c}{ Reference } \\
\cline { 2 - 4 } & Well & Grass & Forest & Row Total & User's accuracy \\
\hline Well & 1 & 0 & 0 & 1 & 100 \\
Grass & 1 & 29 & 2 & 32 & 91 \\
Forest & 1 & 4 & 52 & 57 & 91 \\
Column Total & 3 & 33 & 54 & 90 & \\
Producer's accuracy & 33 & 88 & 96 & & \\
\hline
\end{tabular}

User's accuracies ranged from $72 \%$ to $100 \%$ depending on state and time frame. Accuracies of $100 \%$ were found in all post-development well categories, as well as in the West Virginia pre-development well category. The lowest user's accuracy was determined to be in post-development Pennsylvania imagery when classifying the forests at $72 \%$. User's accuracies at and below $75 \%$ were also calculated in the pre-development time of Pennsylvania for the well and forest categories at 75 and $73 \%$ respectively (Table 5). Having too few accuracy assessment points can produce a lower user's accuracy.

Table 5: Accuracy assessment of the supervised classification for the pre-development time, using 2008 NAIP imagery, for Pennsylvania. Reference numbers represent the ground reference data, while the map numbers represent the classification of each image pixel.

\section{Reference}

\begin{tabular}{llllll}
\cline { 2 - 5 } Map & Well & Grass & Forest & Row Total & User's accuracy \\
\hline Well & 3 & 1 & 0 & 4 & 75 \\
Grass & 1 & 32 & 2 & 35 & 91 \\
Forest & 0 & 14 & 37 & 51 & 73 \\
Column Total & 4 & 47 & 39 & 90 & \\
Producer's accuracy & 75 & 77 & 95 & & \\
\hline
\end{tabular}

\section{Land cover associated with well pads}

The average percentage forest cover within the pre-development well pad buffers from the three state study area was 66.5 percent. The second highest cover type was grass at 31.5 
percent, followed by impervious surfaces at 1.9 percent. During the 10 -year post-development period in 2017, the mean percentage of forested area within the unconventional well pad buffers was 62.2 percent across the region. Areas classified as grass represented 30.7 percent of 10 year post-development buffers, while impervious surfaces represented 7.1 percent of the total land cover (Table 6).

Table 6: Land cover proportion of the well pad buffers in the Appalachian basin.

\begin{tabular}{llllllll}
\hline Time & $\mathbf{n}$ & $\begin{array}{l}\text { Forest } \\
\text { Mean } \\
(\%)\end{array}$ & $\begin{array}{l}\text { Forest } \\
\text { Std. }\end{array}$ & $\begin{array}{l}\text { Impervious } \\
\text { Mev }\end{array}$ & $\begin{array}{l}\text { Impervious } \\
\text { Dev) }\end{array}$ & $\begin{array}{l}\text { Grass } \\
\text { Std. Dev } \\
\text { Mean } \\
\text { (\%) }\end{array}$ & $\begin{array}{l}\text { Grass } \\
\text { Std. } \\
\text { Dev }\end{array}$ \\
\hline Pre-Development & 4212 & 66.5 & 23.3 & 1.9 & 4.8 & 31.5 & 22.3 \\
Post-Development & 4212 & 62.2 & 18.4 & 7.1 & 5.7 & 30.7 & 17.6 \\
\hline
\end{tabular}

The highest average percentage forested land cover during pre and post-development, occurred in West Virginia. Randolph county contained an average of 99.7 percent forested landcover in 2007, while Kanawha county contained an average of 97.5 percent forested land cover in 2017 respectively. The lowest average percentage of forested land cover for both time periods occurred in Ohio. In 2007, Wayne county contained an average of 12.6 percent forested land cover, while in 2017, Morrow county contained an average of 11.2 percent forested land cover respectively.

Morrow county, Ohio, and Clay, Mercer, and Wood counties, West Virginia, did not contain impervious surfaces within the 25-hectare buffers during the pre-development time period. Wood county, West Virginia had an average of 0.2 percent impervious land cover during the post-development time period, which was the lowest county average in the Appalachian basin. Portage county, Ohio contained the highest average impervious surface, 12.9 percent, for the pre-development time. The highest average impervious surface during the postdevelopment time occurred in Warren county, Pennsylvania, with an average of 24.4 percent impervious land cover.

Bedford county, Pennsylvania, Randolph, Raleigh, and Clay counties, West Virginia all contained no grass landcover during the pre-development time. Kanawha county, West Virginia contained the lowest average grass landcover in 2017, at an average of 2.2 percent respectively. The highest grass land cover was found in Medina county, Ohio with an average of 85.6 percent grass land cover in 2007. Morrow county, Ohio contained the highest grass landcover for 2017, with an average of 85.1 percent. 
During the pre-development time period, the average forested area inside the well pad buffers in Pennsylvania was 64.9 percent (Table 7), followed by a decline to 61.0 percent in 2017 (Table 8). The percentage of impervious surface increased from 2.2 percent in 2007, to 7.6 percent in 2017. The average grass percentage in Pennsylvania decreased over the study period, from 33.0 percent, pre-development, to 31.4 percent in the 10 year post-development period.

Table 7: Pre-development land cover percentage by state across the Appalachian basin.

\begin{tabular}{llllllll}
\hline State & $\mathbf{n}$ & $\begin{array}{l}\text { Forest } \\
\text { Mean } \\
(\%)\end{array}$ & $\begin{array}{l}\text { Forest } \\
\text { Std. } \\
\text { Dev }\end{array}$ & $\begin{array}{l}\text { Impervious } \\
\text { Mean (\%) }\end{array}$ & $\begin{array}{l}\text { Impervious } \\
\text { Std. Dev }\end{array}$ & $\begin{array}{l}\text { Grass } \\
\text { Mean } \\
(\%)\end{array}$ & $\begin{array}{l}\text { Grass } \\
\text { Std. } \\
\text { Dev }\end{array}$ \\
\hline Ohio & 691 & 55.0 & 24.1 & 2.1 & 4.6 & 43.0 & 23.0 \\
Pennsylvania & 2741 & 64.9 & 22.1 & 2.2 & 5.4 & 33.0 & 21.2 \\
West Virginia & 780 & 82.7 & 17.4 & 1.1 & 2.4 & 16.2 & 16.8 \\
\hline
\end{tabular}

The average forested percentage for the 10 year post-development well pad buffers was 73.0 percent in West Virginia (Table 8), which had decreased from the pre-development time period of 82.7 percent. The mean percentage of impervious surface increased during the time period from an average of 1.1 percent in 2007 (Table 7), to 4.7 percent in 2017. The average percentage of grass land cover during the pre-development time period was 16.2 percent, which increased to an average of 22.3 percent during the post-development time frame.

Table 8: Post-development land cover percentage by state across the Appalachian basin.

\begin{tabular}{llllllll}
\hline State & $\mathbf{n}$ & $\begin{array}{l}\text { Forest } \\
\text { Mean } \\
(\%)\end{array}$ & $\begin{array}{l}\text { Forest } \\
\text { Std. } \\
\text { Dev }\end{array}$ & $\begin{array}{l}\text { Impervious } \\
\text { Mean (\%) }\end{array}$ & $\begin{array}{l}\text { Impervious } \\
\text { Std. Dev }\end{array}$ & $\begin{array}{l}\text { Grass } \\
\text { Mean } \\
(\%)\end{array}$ & $\begin{array}{l}\text { Grass } \\
\text { Std. } \\
\text { Dev }\end{array}$ \\
\hline Ohio & 691 & 54.5 & 18.1 & 7.8 & 4.0 & 37.7 & 17.5 \\
Pennsylvania & 2741 & 61.0 & 18.0 & 7.6 & 6.3 & 31.4 & 17.6 \\
West Virginia & 780 & 73.0 & 15.2 & 4.7 & 3.7 & 22.3 & 13.6 \\
\hline
\end{tabular}

The average forested percentage within the well pad buffers in Ohio remained consistent during the study period at 55.0 percent in 2007 to 54.5 percent in 2017 . In 2007, the average percentage of impervious surface was 2.1 percent (Table 7). In 2017, the average percentage of impervious surface in Ohio had increased to 7.8 percent. The mean percentage of grass in Ohio during the pre-development time period was 43.0 percent, which dropped to 37.7 percent in 2017 (Table 8). 


\section{Land cover changes associated with UOG development}

Out of the nine possible types of land cover change, three categories were used to monitor change in the land cover due to UOG development: (1) grass to impervious surface, (2) forest to impervious surface, and (3) forest to grass. As a pad is developed, earth is moved, and forested areas that are located near or adjacent to the well pad and associated infrastructure either become part of unconventional development, or are revegetated to grass. Over the three state study area, it was determined that a total of 23,505 hectares of land cover were impacted by UOG development. Pennsylvania contained the most land cover change in the Appalachian region, with 16,846 hectares due to UOG development. West Virginia and Ohio both had similar UOG well pad disturbance, with 3,423, and 3,236 hectares of land cover change, respectively. In Pennsylvania, Washington, Bradford, and Susquehanna counties, had the largest amount of land cover change. Washington and Bradford counties contained 2,874 and 2,858 hectares of disturbance respectively, while Susquehanna county had 2,724 hectares of land cover disturbance. The largest amount of land cover change in West Virginia occurred in Doddridge county, with 502 hectares of land cover change. Belmont county, Ohio had the most disturbance in the state due to UOG development with 617 hectares of land cover change.

The average amount of disturbance per well pad varied by state across the Appalachian basin. The overall disturbance across the region was 5.6 hectares per well pad. Pennsylvania had the largest disturbance per pad with an average of 6.2 hectares disturbed. West Virginia had the smallest disturbance per well pad with an average of 4.4 hectares disturbed, while Ohio had an average disturbance size of 4.7 hectares per well pad.

Of the 23,505 hectares of land cover in the Appalachian basin impacted by UOG development, 16,220 hectares of disturbance were associated with previously, classified forest areas converting to grass land cover. During the study period, 3,703 hectares were converted from grass to an impervious surface land cover, and 3,582 hectares were converted from forest to impervious surface land cover. The forest to grass land cover change is the highest in all three states. Pennsylvania and West Virginia had 11,783, and 2,502 hectares of forest land converted to grass land cover. During the study period, Ohio had 1,934 hectares of forest land converted to grass land cover. Pennsylvania contained 2,644 hectares of forest to impervious surface land cover change. The state also had 2,419 hectares of grass land cover converted to impervious surface land cover during the study period. In West Virginia, 389 hectares of grass 
were converted to impervious surface, while 532 hectares of forest were converted to impervious surface. Ohio contained 406 hectares of forested land cover converted to impervious surface, while 895 hectares of grass land cover were converted to impervious surface.

Washington county, Pennsylvania contained 2,447 hectares of forest to grass conversion between 2007 and 2017. Tioga county had the largest amount of grass to impervious surface land cover in the state of Pennsylvania at 347 hectares respectively. Susquehanna county, Pennsylvania had the largest amount of forest to impervious surface change in the study with 528 hectares of land cover converting.

Doddridge county, West Virginia had the most land cover change in the forest to grass category with 372 hectares of change. Marshall county, West Virginia had the largest amount of grass to impervious surface change with 66 hectares of change occurring throughout the study, while Doddridge county had 107 hectares of forest to grass land cover change in the state.

Unlike Pennsylvania and West Virginia, one county in Ohio had the largest amount of land cover change in each type of change associated with UOG development. Belmont county had 315 hectares of forest land cover change to grass land cover throughout the study period, 221 hectares of grass land cover change to impervious land cover, and 82 hectares of forest land cover change to impervious land cover.

At the individual pad level during the 10-year study period, an average of 3.8 hectares changed from forested land cover to a grass land cover in 2017. During the same study period, an average of 0.9 hectares per buffer changed from grass land cover to impervious land cover, and an average of 0.8 hectares of forested land cover changed to an impervious surface within the 25-hectare buffers across the Appalachian region, respectively. Overall, the amount of land area that differed among change type (forest to grass, forest to impervious, and grass to impervious) was significant $(p<0.0001)$ as was the total change in land cover type among states $(p<0.0001)$. The interaction among change type and state was also significant $(p<0.0001)$ and is the better descriptor of change type and state.

According to the results from the mixed model analysis of variance, Pennsylvania had a significantly greater change in forest cover to grass $(p<0.0001)$ of 4.3 hectares per buffer versus a change of 3.2 hectares in West Virginia, and 2.8 hectares in Ohio (Figure 7). Pennsylvania also had a significantly greater change in forest cover to impervious surface $(p<0.0001)$ of 1 hectare per buffer, in comparison to 0.7 hectares in West Virginia, and 0.6 hectares in Ohio. The 
grass to impervious surface change was significantly higher $(\mathrm{p}<0.0001)$ in Ohio, with a mean change of 1.3 hectares per buffer versus 0.9 hectares in Pennsylvania, and 0.5 hectares in West Virginia. Pennsylvania also had a significantly greater change in grass to impervious surface $(p<0.0001)$ of 0.9 hectares per buffer versus a change of 0.5 hectares West Virginia.

Bedford county, Pennsylvania contained no forested to grass land cover change during the study period. Washington county, Pennsylvania contained the highest forest to grass land cover change, with an average change of 8.3 hectares per buffer respectively. Six counties in the study area that did not show a grass to impervious cover change were Marion county Ohio, and Braxton, Clay, Jackson, Raleigh, and Randolph counties, West Virginia. The largest land cover mean change occurred in Warren county, Pennsylvania, with an average of 4.3 hectares per buffer change of grass land cover to impervious across two well pad buffers. Five counties, across all three states had no change in landcover from the forest category to the impervious category. Those counties included Medina, and Morrow county, Ohio, Lackawanna county, Pennsylvania, and Jackson, and Wood county, West Virginia. Clearfield county, Pennsylvania contained an average of 5.4 hectares per buffer of land cover change from forest to impervious throughout the study period (Table 9). 
Table 9: Land cover change across Pennsylvania in acres, showing only those counties with 10 or more buffers

\begin{tabular}{lllllll}
\hline County & $\begin{array}{l}\text { Forest to } \\
\text { Impervious } \\
\text { (Mean) }\end{array}$ & $\begin{array}{l}\text { Forest to } \\
\text { Impervious } \\
\text { (Std. Dev) }\end{array}$ & $\begin{array}{l}\text { Grass to } \\
\text { Impervious } \\
\text { (Mean) }\end{array}$ & $\begin{array}{l}\text { Grass to } \\
\text { Impervious } \\
\text { (Std. Dev) }\end{array}$ & $\begin{array}{l}\text { Forest to } \\
\text { Grass } \\
\text { (Mean) }\end{array}$ & $\begin{array}{l}\text { Forest to } \\
\text { Grass (Std. } \\
\text { Dev) }\end{array}$ \\
\hline Allegheny & 3.0 & 2.7 & 3.6 & 4.2 & 6.6 & 4.7 \\
Armstrong & 0.9 & 1.2 & 3.5 & 3.5 & 6.6 & 6.7 \\
Beaver & 1.9 & 1.7 & 2.4 & 2.2 & 7.9 & 3.9 \\
Bradford & 1.5 & 1.6 & 1.4 & 1.7 & 10.1 & 7.2 \\
Butler & 1.9 & 2.7 & 5.1 & 4.8 & 5.9 & 3.2 \\
Cameron & 3.8 & 3.0 & 0.9 & 0.9 & 13.0 & 5.8 \\
Centre & 1.6 & 1.5 & 0.6 & 0.8 & 13.6 & 7.4 \\
Clarion & 1.7 & 1.0 & 5.5 & 4.7 & 5.2 & 3.2 \\
Clearfield & 13.4 & 11.2 & 5.7 & 6.5 & 1.9 & 1.8 \\
Clinton & 2.9 & 1.3 & 0.4 & 0.4 & 13.4 & 5.9 \\
Elk & 3.6 & 1.7 & 0.7 & 0.9 & 10.2 & 6.5 \\
Fayette & 1.0 & 1.2 & 3.1 & 4.3 & 8.0 & 4.9 \\
Greene & 2.5 & 2.0 & 2.0 & 2.1 & 12.1 & 6.0 \\
Indiana & 1.3 & 1.3 & 3.0 & 3.4 & 5.2 & 2.8 \\
Jefferson & 1.5 & 1.5 & 4.0 & 6.3 & 9.8 & 6.1 \\
Lawrence & 0.9 & 1.5 & 6.4 & 4.7 & 5.1 & 3.6 \\
Lycoming & 2.8 & 2.1 & 1.4 & 2.0 & 4.7 & 3.5 \\
McKean & 2.2 & 1.7 & 1.4 & 1.4 & 5.7 & 4.8 \\
Mercer & 0.9 & 0.7 & 4.2 & 3.6 & 4.7 & 2.3 \\
Potter & 1.7 & 2.5 & 0.6 & 0.8 & 12.7 & 7.1 \\
Somerset & 2.9 & 2.1 & 2.5 & 3.2 & 15.3 & 11.6 \\
Sullivan & 1.5 & 1.2 & 1.7 & 1.4 & 4.8 & 4.0 \\
Susquehanna & 3.3 & 2.3 & 2.1 & 2.4 & 11.7 & 5.9 \\
Tioga & 1.8 & 1.7 & 3.5 & 3.0 & 10.9 & 6.2 \\
Washington & 2.5 & 1.9 & 1.1 & 1.2 & 20.6 & 7.9 \\
Westmoreland & 0.8 & 1.0 & 2.2 & 1.8 & 7.9 & 6.5 \\
Wyoming & 2.5 & 2.4 & 2.3 & 2.6 & 17.8 & 6.6 \\
Total & $\mathbf{2 . 4}$ & $\mathbf{2 . 9}$ & $\mathbf{2 . 2}$ & $\mathbf{2 . 9}$ & $\mathbf{1 0 . 6}$ & $\mathbf{7 . 6}$ \\
\hline & & & & & & \\
\hline
\end{tabular}




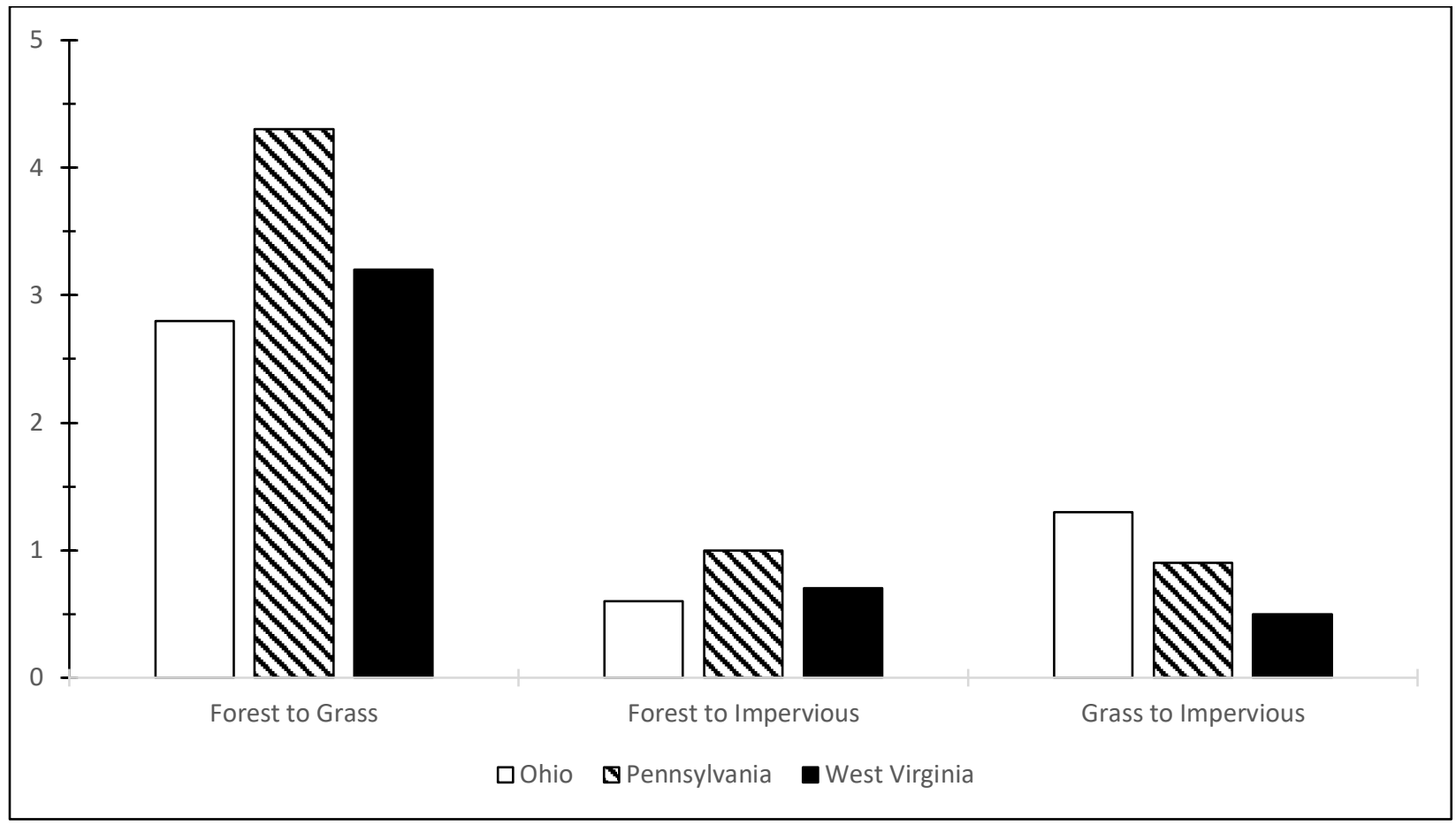

Figure 7: The average land cover disturbance (ha), per well pad, associated with UOG development across the Appalachian basin.

\section{Pre and Future Development Land Cover Characteristics}

\section{Pre-Development Site Characteristics}

There was no significant difference $(p=0.0512)$ in forested percent between known unconventional developed areas, and the random buffers. The average percent forested in the 25-hectare active well buffers was 67.2 percent, while the average percent forest in the random buffers was 75.5 percent, respectively. The grass land cover on the 25 -hectare buffers that have been developed was significantly higher $(p=0.0021)$, with a mean of 31.1 percent, than the grass percentage in the completely random buffers with a mean of 22.7 percent. There was no difference $(p=0.605)$ in the means between the impervious percent on the developed buffers and the random buffers, each had an average of 1.8 percent.

Pre-land cover characteristics were also summarized for the top three unconventionally developed counties in each state. Bradford county, Pennsylvania contained an average of 80.1 percent forested area, 1.1 percent impervious surface, and 18.8 percent grass land cover over the randomly selected buffered areas. In 2007, Bradford county contained 66.4 percent forested 
areas, 1.8 percent impervious surface, and 31.9 percent of grass land cover within the original 25-hectare well pad buffers. The previously selected well pad buffers contained a lower forested land cover percentage, but a higher impervious surface, and grass land cover percentage than the randomly selected buffers captured.

Doddridge county, West Virginia, contained an average of 92.4 percent forested land cover within the thirty random buffers across the county (Table 10). The pre-development well pad buffers captured a lower forest percentage than the random buffers in the county at 90.5 percent. The grass percentage in Doddridge county within the random buffers was 7.0 percent, which is lower than the grass land cover found within the well pad buffers at 8.3 percent. Impervious surface land cover was also higher in the well pad buffers than in the random buffers across the county. Doddridge county had an impervious surface land cover of 1.3 percent within the well pad buffers, and 0.6 percent within the random buffers.

Belmont county, Ohio contained the smallest forested percent with an average of 54.1 percent in the random buffers. The average forested percent within the pre-development well pad buffers was similar at 52.4 percent respectively. The mean grass percentage for the county was 42.2 percent within the random buffers, while the grass land cover percentage was 45.5 percent in the well pad buffers. In 2007, the mean impervious surface percent was 3.7 percent within the random buffers, and 2.2 percent within the existing well pad buffers.

Table 10: Pre-development land cover, in percent, of areas within the random 25-ha buffers. The counties selected are the county with the most wells drilled per state.

\begin{tabular}{lllllll} 
County & $\begin{array}{l}\text { Forest } \\
\text { Mean (\%) }\end{array}$ & $\begin{array}{l}\text { Forest } \\
\text { Std. Dev }\end{array}$ & $\begin{array}{l}\text { Impervious } \\
\text { Mean (\%) }\end{array}$ & $\begin{array}{l}\text { Impervious } \\
\text { Std. Dev }\end{array}$ & $\begin{array}{l}\text { Grass } \\
\text { Mean (\%) }\end{array}$ & $\begin{array}{l}\text { Grass } \\
\text { Std. Dev }\end{array}$ \\
\hline Belmont & 54.1 & 26.6 & 3.7 & 6.8 & 42.2 & 24.3 \\
Bradford & 80.1 & 13.7 & 1.1 & 1.5 & 18.8 & 13.0 \\
Doddridge & 92.4 & 10.7 & 0.6 & 1.2 & 7.0 & 10.0 \\
\hline
\end{tabular}

\section{Potential Characteristics of Future Development}

Forest land cover comprised 79.9 percent of the landscape outside of producing buffers in the three county study area. Impervious surface comprises 2.3 percent of the landscape, while grass land cover is 17.8 percent, respectively. Bradford county, Pennsylvania contained an average of 76.0 percent forest, 3.5 percent impervious surface, and 20.5 percent grass land cover within the random undeveloped well pad buffers. In the undeveloped random buffers of Doddridge county, West Virginia the land cover consisted of 91.2 percent forested, 0.4 percent 
impervious cover, and an average of 8.4 percent of grass respectively (Table 11). Belmont county, Ohio contained an average of 72.4 percent forest, 3.0 percent impervious surface, and an average of 24.5 percent grass land cover across the undeveloped random buffers.

Table 11: Land cover percentage of areas that have not been developed, as of 2017. The counties selected are the county with the most wells drilled per state.

\begin{tabular}{lllllll}
\hline County & $\begin{array}{l}\text { Forest } \\
\text { Mean (\%) }\end{array}$ & $\begin{array}{l}\text { Forest } \\
\text { Std. Dev }\end{array}$ & $\begin{array}{l}\text { Impervious } \\
\text { Mean (\%) }\end{array}$ & $\begin{array}{l}\text { Impervious } \\
\text { Std. Dev }\end{array}$ & $\begin{array}{l}\text { Grass } \\
\text { Mean (\%) }\end{array}$ & $\begin{array}{l}\text { Grass } \\
\text { Std. Dev }\end{array}$ \\
\hline Belmont & 72.4 & 15.1 & 3.0 & 5.1 & 24.5 & 12.4 \\
Bradford & 76.0 & 22.2 & 3.5 & 8.6 & 20.5 & 18.6 \\
Doddridge & 91.2 & 9.6 & 0.4 & 1.1 & 8.4 & 9.6 \\
\hline
\end{tabular}

\section{Discussion}

In the 10-year period of this study, natural gas production in the Appalachian region grew from 1.2 BCF per day in January of 2007 to 26.9 BCF per day in December of 2017, representing an increase of 2142 percent (U.S. Energy Information Administration, 2020). This level of increase changed the energy production of the United States from a net importer of 3.8 TCF in 2007 to a net importer of -0.12 TCF in 2017 (U.S. Energy Information Administration, 2019c). All of the production increases in the past decade across the region, are linked to Pennsylvania, West Virginia, and Ohio (U.S. Energy Information Administration, 2019a). The other states that are within the Marcellus and Utica shale (Maryland and New York), have a moratorium on natural gas drilling (Hastings et al., 2017; Leff, 2015; Sangaramoorthy, 2018). With these increases in production, associated increases in land cover change have occurred. Much of the drilling has taken place in rural areas, which can focus change on the conversion of forest and grass lands to a more industrial land use type.

There have been many studies that have attempted to measure this change, but none have been done across the entire Appalachian basin. In June of 2011, Drohan (et al. 2012) reported that of the 3,364 wells permitted in Pennsylvania, 2,931 were considered active. The number of permitted and active wells rose drastically to 17,609 permitted, and 15,474 active wells as of December 31,2017. The size of the pads has also increased, thus requiring larger well pads and potentially greater levels of land use change. In the same study, Drohan (et al. 2012) concluded that over 75 percent of well pads in the state of Pennsylvania contained 1 to 2 wells. As predicted, that number has increased, with the average well pad in Pennsylvania currently containing 5.6 wells. As companies have signed leases with land owners, and laid 
claim to as much of the land as possible, they are now going back and adding more wells to each well pad. Currently, West Virginia has an average of 5 wells per pad. In Ohio, there are currently an average of 3.8 wells per pad, which is considerably less than in Pennsylvania. The increase in unconventional drilling activity started in Ohio approximately three years after Pennsylvania.

Overall classification accuracies ranged from 80 percent for the pre-development Pennsylvania classification, to 94 percent for the post West Virginia classification. Pennsylvania post-development overall classification accuracies were the second lowest of all three states with an 84 percent accuracy. Compared to the other two states, Pennsylvania had the largest area classified. One way to increase the overall accuracies in the study would be to use more training data. Using more training data would give each class broader spectral properties, which would allow the classification algorithm to classify the correct land cover types more accurately, but would increase the amount of processing time. Since the study extent was the entire Appalachian basin, the number of training samples were chosen so that the computer processing could be completed in a feasible time period.

All user's and producer's accuracies were above 70 percent, except for producer's accuracy of impervious surface for the pre-development time in West Virginia (33 percent). The producer's accuracy was low, due to there being only three impervious surface reference points within the pre-development imagery. By having more random data points to test the accuracy of the classification process, there would be a less likely chance of having such a small accuracy level.

The average amount of disturbance due to UOG activities was similar throughout the Appalachian basin. This study determined the well pad disturbance due to UOG development was higher than previously conducted studies with an average of 5.6 hectares per well. This estimate includes all of the disturbance within the 25-hectare buffer, representing the well pad, access roads and additional infrastructure related to UOG development including pipelines and water containment. Johnson (et al 2010) found a disturbance size of approximately 3.6 hectares per pad, while studies in Tioga, Greene, Bradford, and Washington, counties, Pennsylvania found the average disturbance per pad to be between 2.7 and 3 hectares respectively (Slonecker, Milheim, Roig-Silva, \& Fisher, 2012; Slonecker, Milheim, Roig-Silva, Malizia, et al., 2012). Jantz (et al. 2014) found that each well pad in Bradford county, Pennsylvania had an average size of 2.5 hectares, while the additional infrastructure associated with it disturbed an 
additional 1.6 hectares of landscape. Langlois (et al. 2017) used a $2 \mathrm{~km}$ buffer to assess the spatial disturbance of UOG development, and discovered that the average well pad disturbed 2.2 hectares of landcover, while the associated secondary infrastructure disturbed an additional 7.7 hectares of landcover.

Only one study on land cover change and characteristics of UOG development in the Appalachian basin, have taken place outside the state of Pennsylvania. Zinkhan Jr (2016) found the average disturbance associated with UOG wells in West Virginia to be 3.6 hectares per well pad. In this study, we found that disturbance related to unconventional development was approximately 22 percent higher than Zinkhan Jr (2016). Several reasons can account for the greater level of disturbance found in this study. It can primarily be accounted for by the size of the buffer used (25 hectare versus 20 hectare in Zinkhan Jr (2016)) as well as the trend in well bores per pad. As unconventional development matured in the region, a greater number of wells are drilled on each pad, thus increasing the surface infrastructure needed for each site.

In West Virginia, forest land has been stable over the last three decades (Morin, Domke, \& Walters, 2017). Pennsylvania's forest land has also been stable over the last three decades, with a gradual increase in the volume of the forests (Albright, 2017). Pennsylvania's commonwealth consists of approximately 58 percent forested areas, while West Virginia contains approximately 78 percent forested areas (Albright, 2017; Morin et al., 2017). The highest average change in land cover across the Appalachian region was forested areas to grass. The majority of this change was accounted for directly surrounding the well pad. In areas with steep topography, the cleared area for the well pad can be larger than needed because of the increased area needed for cut and fill slopes. Once the pad is developed, the remaining areas surrounding the well pad are usually barren soil, which must then be seeded with grass species (WV DEP, 2012). Grass land cover helps with erosion control, and can also be important habitat for multiple types of wildlife (Villemey et al., 2018). Although many UOG well pads have not been reclaimed yet, most BMPs require the site be reclaimed back to original contour upon completion. In a study by Drohan \& Brittingham (2012), it was found that reclaimed wells did convert back to agricultural crop production after UOG development. The biggest limitation to revegetation success of species on disturbed areas, is poor soil reclamation (Drohan \& Brittingham, 2012).

Unlike grass, impervious surface land cover is unnatural, and has little ecological use for wildlife. As impervious surface increases across the landscape, there will be a higher rate of 
water runoff and soil erosion across the Appalachian basin. Entrekin (et al., 2011) found that well development can lead to higher sediment inputs into the nearby surface waters, which can have negative effects including eutrophication. One of the primary BMP strategies used to reduce the amount of sedimentation into surface waters is the use of a sediment fence, or filter sock (Grushecky, McDonald, \& Osborn, 2019). Both options provide a barrier to allow the sedimentation to stay on site, while allowing water to pass through.

The pre-development site characteristics were studied in a one county area from each state in the study region. Although each county has the greatest level of development in the state, they do not accurately depict the characteristics throughout the Appalachian region. It was found that grass cover on the well pads was significantly greater than on the random buffers. This suggests that the UOG companies were locating wells on areas with a higher grass percentage. There are a few reasons, as to why wells would be more likely found on grass. The cost of developing a well pad in a forested land cover is much higher in comparison to one in a grass land cover. It is more expensive and time consuming to remove trees and stumps from a location. Forests also tend to be typically more rugged than grass landscapes, meaning that they will be harder to work on due to uneven ground, and higher slopes. Areas that are currently grass land cover in the Appalachian basin are typically used as agricultural fields and pastures, which are already located on flatter ground, such as on hilltops. Another reason that UOG wells are preferentially placed in more grass areas are because of timber cutting restrictions associated with endangered species(U.S. Fish and Wildlife Service, 2011). Timber cutting restrictions are implemented in some areas where there is a potential overlap with an endangered species, such as the Indiana bat (Myotis sodalist). Currently in West Virginia, an Indiana bat conservation plan is needed if clearing more than 17 acres of forest (West Virginia Field Office, n.d.). If the bats are found on the location, then the timber must be cut seasonally, which can be a large inconvenience to the oil and gas companies.

Conversion of forest to grass and impervious surface can negatively affect wildlife, especially those forest interior species such as the cerulean warbler, mourning warbler, and northern goshawk. Although the disturbance does not favor forest interior species, disturbance creating edge habitat is not bad for all types of wildlife. A study by Villemey (et al., 2018), documented increased insect abundance on linear infrastructure. Many species such as the Indiana bat forage on insects, which can be found surrounding UOG development (Sparks, Ritzi, Duchamp, \& Whitaker, 2005). 
The potential impacts of future development on site characteristics were studied in a one county area from each state in the study region. While this represents those counties with the greatest level of development, it does not accurately depict potential land cover changes throughout the Appalachian region. Results from this indicate that areas outside of DPUs had greater levels of forest cover than those that had already been developed. The undeveloped areas also contained less grass, and less impervious surface than found in the developed well pad buffers. Since there is less grass available for development, future development patterns will have a larger impact on forest resources. Our prediction that future UOG development will have a larger impact on the forest land cover is also consistent with research by Drohan (et al., 2012). Because UOG development has preferentially been confined to areas with more grass, there is not as much grass land cover available for future UOG development. Since only the three top counties in each state were included in the study, we cannot imply that the trend will be consistent for the entire basin, but it is the trend for those counties included in the study.

\section{Conclusion}

Since each step of the study was done on a county level, the average time spent was approximately 6 hours per county. In the 6 hour time, it was possible to download and clip the imagery to the 25-ha buffers, create the signature file, and run the maximum likelihood classifier and majority filter tools. Processing time varied depending on size of county, size of imagery, and amount of 25-ha buffers. A similar approach could be used to determine the amount of disturbance associated with other UOG infrastructure. Compressor stations must be permitted in a similar manner to UOG wells, so similar methods would identify disturbance associated with them. Pipelines would be more complex to identify, since there is no single database with all gathering pipeline locational information available. To use a supervised classification, high resolution imagery would have to be used to digitize pipeline locations, which would be time consuming on a state by state basis. Once the locations were digitized, a buffer could be placed, and the imagery could be classified with similar methodology. One way to make the supervised classification process more efficient, would be to use computers with larger processing power, which would reduce waiting times.

As the wells per pad increases throughout the Appalachian basin, there will be less disturbance associated with UOG production. On average, there are 5.2 wells per pad across the Appalachian basin, disturbing an average of 5.6 hectares of forest and grass landcover. 
Across the region, 4.3 percent of forest was lost, 0.8 percent grass was lost, and 5.2 percent of impervious surface was gained directly surrounding UOG development. West Virginia was the only state that gained grass throughout the study. Over the study area, it was determined that 23,505 hectares of land cover were impacted by UOG development, of which 16,220 hectares were forest land that was converted to grass land cover. The percentage of grass land cover was significantly higher on well pad locations, than at random areas throughout Belmont, Bradford, and Doddridge counties. In those same counties, the percentage of forest were higher in undeveloped areas, suggesting that as more UOG development occurs across the Appalachian basin, forest land cover will be impacted at higher rates. To further address the landscape impacts associated with UOG development, other landscape metrics such as forest fragmentation, and edge effects, should be used in conjunction with land cover data to provide a complete analysis. 


\section{Literature Cited}

Abrahams, L. S., Griffin, W. M., \& Matthews, H. S. (2015). Assessment of policies to reduce core forest fragmentation from Marcellus shale development in Pennsylvania. Ecological Indicators, 52(1), 153-160. https://doi.org/10.1016/j.ecolind.2014.11.031

Albright, T. A. (2017). Forests of Pennsylvania. United States Department of Agriculture, (August), 1-4. Retrieved from https://www.fs.fed.us/nrs/pubs/ru/ru_fs21.pdf

Armstrong, K., Card, R., Navarrete, R., Nelson, E., Nimerick, K., \& Samuelson, M. (1995). Advanced Fracturing Fluids Improve Well Economics. Oilfield Review, 7(3), 34-51. https://doi.org/10.1016/0148-9062(96)80066-0

Arthur, D., \& Cornue, D. (2010). Technologies Reduce Pad Size , Waste. The American Oil\&Gas Reporter, (August), 1-4.

Bearer, S., Nicholas, E., Gagnolet, T., DePhilip, M., Moberg, T., \& Johnson, N. (2012). Evaluating the scientific support of conservation best management practices for shale gas extraction in the appalachian basin. Environmental Practice, 14(4), 308-319. https://doi.org/10.1017/S1466046612000385

Boudet, H., Clarke, C., Bugden, D., Maibach, E., Roser-Renouf, C., \& Leiserowitz, A. (2014). "Fracking" controversy and communication: Using national survey data to understand public perceptions of hydraulic fracturing. Energy Policy, 65, 57-67. https://doi.org/10.1016/j.enpol.2013.10.017

Clean Water Act, Pub. L. No. 1251 et seq. (1972).

Cook, T., Perrin, J., \& Van Wagener, D. (2018). Hydraulically fractured horizontal wells account for most new oil and natural gas wells.

Drohan, P. J., \& Brittingham, M. (2012). Topographic and Soil Constraints to Shale-Gas Development in the Northcentral Appalachians. Soil Science Society of America Journal, 76(5), 1696-1706. https://doi.org/10.2136/sssaj2012.0087

Drohan, P. J., Brittingham, M., Bishop, J., \& Yoder, K. (2012). Early Trends in Landcover Change and Forest Fragmentation Due to Shale-Gas Development in Pennsylvania: A Potential Outcome for the Northcentral Appalachians. Environmental Management, 49, 1061-1075. https://doi.org/10.1007/s00267-012-9841-6 
Endangered Species Act, Pub. L. No. 1531-1544 (1973).

Entrekin, S., Evans-White, M., Johnson, B., \& Hagenbuch, E. (2011). Rapid expansion of natural gas development poses a threat to surface waters. Frontiers in Ecology and the Environment, 9(9), 503-511. https://doi.org/10.1890/110053

ESRI. (2019). ArcGIS and Spatial Analyst Extension. Environmental Systems Research Institute, Redlands, CA.

Evans, J. S., \& Kiesecker, J. M. (2014). Shale gas, wind and water: Assessing the potential cumulative impacts of energy development on ecosystem services within the Marcellus play. PLoS ONE, 9(2), 1-9. https://doi.org/10.1371/journal.pone.0089210

Franklin, S. E. (2018). Pixel and object-based multispectral classification of forest tree species from small unmanned aerial vehicles. Unmanned Vehicle Systems, 17, 1-17.

Geary, E. (2019). U.S. natural gas production hit a new record high in 2018. Retrieved February 1, 2020, from https://www.eia.gov/todayinenergy/detail.php?id=38692

Governor's Marcellus Shale Advisory Commission Report. (2011).

Grushecky, S. T., McDonald, L. M., \& Osborn, L. (2019). The use of woods-run chips in filter socks to control erosion and sedimentation during petroleum development in the Appalachian Basin. International Journal of Sediment Research, 34(6), 608-615. https://doi.org/10.1016/j.ijsrc.2018.12.001

Hastings, K., Heller, L. R., \& Stephenson, E. F. (2017). Fracking and Labor Market Conditions: A Comparison of Pennsylvania and New York Border Counties. Eastern Economic Journal, 43, 649-659. https://doi.org/10.1057/eej.2015.47

Horizontal Well Act, Pub. L. No. 6A (2011). 22.

Jackson, R. B., Vengosh, A., Carey, J. W., Davies, R. J., Darrah, T. H., O'Sullivan, F., \& Petron, G. (2014). The Environmental Costs and Benefits of Fracking. Annual Review of Environment and Resources, 39, 327-362. https://doi.org/10.1146/annurev-environ031113-144051

Jantz, C. A., Kubach, H. K., Ward, J. R., Wiley, S., \& Heston, D. (2014). Assessing Land Use Changes Due to Natural Gas Drilling Operations in the Marcellus Shale in Bradford County, PA. The Geographical Bulletin, 55, 18-35. 
Johnson, N., Gagnolet, T., Ralls, R., Zimmerman, E., Eichelberger, B., Tracey, C., ... Sargent, S. (2010). Pennsylvania Energy Impacts Assessment.

Kargbo, D. M., Wilhelm, R. G., \& Campbell, D. J. (2010). Natural gas plays in the marcellus shale: Challenges and potential opportunities. Environmental Science and Technology, 44, 5679-5684. https://doi.org/10.1021/es903811p

Langlois, L. A., Drohan, P. J., \& Brittingham, M. C. (2017). Linear infrastructure drives habitat conversion and forest fragmentation associated with Marcellus shale gas development in a forested landscape. Journal of Environmental Management, 197, 167-176.

https://doi.org/10.1016/j.jenvman.2017.03.045

Law, B. ., \& Curtis, J. . (2002). Introduction to unconventional petroleum systems. AAPG Bulletin, 86(11), 1851-1852. https://doi.org/10.1016/b978-044450525-5/50010-x

Leff, E. (2015). Final Supplemental Generic Environmental Impact Statement on the Oil, Gas and Solution Mining Regulatory Program. Retrieved from www.dec.ny.gov

Makki, T., Fakheran, S., Moradi, H., Iravani, M., \& Senn, J. (2013). Landscape-scale impacts of transportation infrastructure on spatial dynamics of two vulnerable ungulate species in Ghamishloo Wildlife Refuge, Iran. Ecological Indicators, 31, 6-14. https://doi.org/10.1016/j.ecolind.2013.03.001

Morin, R. S., Domke, G. M., \& Walters, B. F. (2017). Forests of West Virginia, (June), 3-6. https://doi.org/https://doi.org/10.2737/FS-RU-123

Myint, S. W., Gober, P., Brazel, A., Grossman-Clarke, S., \& Weng, Q. (2011). Per-pixel vs. object-based classification of urban land cover extraction using high spatial resolution imagery. Remote Sensing of Environment, 115(5), 1145-1161. https://doi.org/10.1016/j.rse.2010.12.017

Norris, J. Q., Turcotte, D. L., Moores, E. M., Brodsky, E. E., \& Rundle, J. B. (2016). Fracking in Tight Shales: What Is It, What Does It Accomplish, and What Are Its Consequences? Annual Review of Earth and Planetary Sciences, 44(1), 321-351. https://doi.org/10.1146/annurev-earth-060115-012537

Ohio Administrative Code (2019).

Olmstead, S. M., Muehlenbachs, L. A., Shih, J. S., Chu, Z., \& Krupnick, A. J. (2013). Shale gas 
development impacts on surface water quality in Pennsylvania. Proceedings of the National Academy of Sciences of the United States of America, 110(13), 4962-4967. https://doi.org/10.1073/pnas.1213871110

Olofsson, P., Foody, G. M., Herold, M., Stehman, S. V., Woodcock, C. E., \& Wulder, M. A. (2014). Good practices for estimating area and assessing accuracy of land change. Remote Sensing of Environment, 148, 42-57. https://doi.org/10.1016/j.rse.2014.02.015

Olofsson, P., Foody, G. M., Stehman, S. V., \& Woodcock, C. E. (2012). Making better use of accuracy data in land change studies: Estimating accuracy and area and quantifying uncertainty using stratified estimation. Remote Sensing of Environment, 129, 122-131. https://doi.org/10.1016/j.rse.2012.10.031

Pa General Assembly. Act 13 (2012).

PHMSA. (2019). Electronic Code of Federal Regulations. Retrieved from https://www.ecfr.gov/cgi-bin/text\%09idx?SID=1d49a3b137cb1b6fc45251074e634b44\&tpl=/ecfrbrowse/Title49/49tab_02.tpl

Popova, O. (2017a). Marcellus Shale Play: Geology Review. Retrieved from www.eia.gov

Popova, O. (2017b). Utica Shale Play: Geology Review.

Riitters, K. H., Wickham, J. D., O'Neill, R. V, Jones, K. B., Smith, E. R., Coulston, J. W., ... Smith, J. H. (2002). Fragmentation of Continental United States Forests. Ecosystems, 5(8), 815-822. https://doi.org/10.1007/s10021002-0209-2

Sangaramoorthy, T. (2018). Maryland is not for Shale: Scientific and public anxieties of predicting health impacts of fracking. Extractive Industries and Society, 6(2), 463-470. https://doi.org/10.1016/j.exis.2018.11.003

Slonecker, E. T., Milheim, L. E., Roig-Silva, C. M., \& Fisher, G. B. (2012). Landscape Consequences of Natural Gas Extraction in Greene and Tioga Counties, Pennsylvania, 2004-2010. Retrieved from http://www.usgs.gov/pubprod

Slonecker, E. T., Milheim, L., Roig-Silva, C., Malizia, A., Marr, D., \& Fisher, G. (2012). Landscape Consequences of Natural Gas Extraction in Bradford and Washington Counties, Pennsy/vania, 2004-2010. Retrieved from http://www.usgs.gov/pubprod

Song, Y., Zhuo, L., Jiang, L., \& Hong, F. (2015). The concept and the accumulation 
characteristics of unconventional hydrocarbon resources. Petroleum Science, 12(4), 563572. https://doi.org/10.1007/s12182-015-0060-7

Sparks, D. W., Ritzi, C. M., Duchamp, J. E., \& Whitaker, J. O. (2005). Foraging Habitat of the Indiana Bat (Myotis Sodalis) At an Urban-Rural Interface. Journal of Mammalogy, 86(4), 713-718. https://doi.org/10.1644/1545-1542(2005)086[0713:fhotib]2.0.co;2

Strager, M. (2008). Accuracy Assessment. Retrieved from https://docs.google.com/presentation/d/190CZGDJ0wm5js1wC6BlqpNOuOUPcKSG05IqD_RFzc/edit\#slide=id.p1

The Clean Streams Law (2006).

The Nature Conservancy. (2014). Land Use and Ecological Impacts from Shale Development in the Appalachians.

U.S. Department of Energy. (2009). Modern Shale Gas Development in the United States: A Primer. https://doi.org/DE-FG26-04NT15455, 98p. : www.netl.doe.gov/technologies/oilgas/publications/epreports/shale_gas_primer_2009.pdf

U.S. Energy Information Administration. (2016). Maps: Oil and Gas Exploration, Resources, and Production.

U.S. Energy Information Administration. (2019a). December 2019 Monthly Energy Review. U.S. Energy Information Administration. https://doi.org/10.1044/leader.ppl.24062019.28

U.S. Energy Information Administration. (2019b). Glossary.

U.S. Energy Information Administration. (2019c). Natural gas explained.

U.S. Energy Information Administration. (2019d). U . S . Crude Oil and Natural Gas Proved Reserves, Year-end 2018, (December).

U.S. Energy Information Administration. (2020). Drilling Productivity Report.

U.S. Fish and Wildlife Service. (2011). Guidence on Developing and Implementing an Indiana Bat Conservation Program.

Villemey, A., Jeusset, A., Vargac, M., Bertheau, Y., Coulon, A., Touroult, J., ... Sordello, R. (2018). Can linear transportation infrastructure verges constitute a habitat and/or a corridor for insects in temperate landscapes? A systematic review. Environmental Evidence, 7, 1- 
33. https://doi.org/10.1186/s13750-018-0117-3

West Virginia Field Office. (n.d.). Frequently Asked Questions.

Williams, H. F. L., Havens, D. L., Banks, K. E., \& Wachal, D. J. (2008). Field-based monitoring of sediment runoff from natural gas well sites in Denton County, Texas, USA. Environmental Geology, 55(7), 1463-1471. https://doi.org/10.1007/s00254-007-1096-9

WV DEP. (2012). West Virginia Erosion and Sediment Control Field Manual.

WVDEP. (2020). Office of Oil and Gas Well Locations.

Young, J., Maloney, K. O., Slonecker, E. T., Milheim, L. E., \& Siripoonsup, D. (2018). Canopy volume removal from oil and gas development activity in the upper Susquehanna River basin in Pennsylvania and New York (USA): An assessment using lidar data. Journal of Environmental Management, 222, 66-75. https://doi.org/10.1016/j.jenvman.2018.05.041

Zinkhan Jr, F. C. (2016). Site Characteristics Associated with Conventional and Unconventional Petroleum Development in West Virginia. 


\section{Appendix}

Table 1a: Pre-Development land cover area by county in Ohio, displaying counties that had at least 10 well buffers within them from 2007 to 2017.

\begin{tabular}{llllllll}
\hline County & $\mathbf{n}$ & $\begin{array}{l}\text { Forest } \\
\text { Mean } \\
\text { (Ac) }\end{array}$ & $\begin{array}{l}\text { Forest } \\
\text { Std. Dev }\end{array}$ & $\begin{array}{l}\text { Well } \\
\text { Mean } \\
\text { (Ac) }\end{array}$ & $\begin{array}{l}\text { Well } \\
\text { Std. Dev }\end{array}$ & $\begin{array}{l}\text { Grass } \\
\text { Mean } \\
\text { (Ac) }\end{array}$ & $\begin{array}{l}\text { Grass } \\
\text { Std. Dev }\end{array}$ \\
\hline Belmont & 123 & 35.4 & 17.8 & 1.6 & 2.6 & 31.8 & 19.8 \\
Carroll & 122 & 27.6 & 11.0 & 1.0 & 1.5 & 36.0 & 11.1 \\
Columbiana & 55 & 30.6 & 13.9 & 3.0 & 4.9 & 29.3 & 12.7 \\
Guernsey & 51 & 38.9 & 14.9 & 1.4 & 3.7 & 25.5 & 15.7 \\
Harrison & 91 & 38.7 & 14.8 & 1.0 & 2.5 & 24.7 & 14.8 \\
Jefferson & 53 & 35.3 & 14.6 & 0.7 & 1.4 & 28.3 & 16.6 \\
Monroe & 78 & 47.5 & 14.7 & 0.5 & 0.8 & 17.5 & 12.2 \\
Noble & 44 & 49.8 & 15.8 & 0.8 & 1.8 & 16.2 & 11.3 \\
Stark & 13 & 26.2 & 15.4 & 1.2 & 1.2 & 34.5 & 14.8 \\
Trumbull & 12 & 24.4 & 12.6 & 6.6 & 5.1 & 31.4 & 10.6 \\
Tuscarawas & 10 & 26.2 & 16.2 & 1.4 & 2.3 & 35.3 & 15.8 \\
Total & $\mathbf{6 9 1}$ & $\mathbf{3 5 . 8}$ & $\mathbf{1 6 . 3}$ & $\mathbf{1 . 4}$ & $\mathbf{3 . 0}$ & $\mathbf{2 8 . 1}$ & $\mathbf{1 6 . 0}$ \\
\hline
\end{tabular}

Table 2a: Post-Development land cover area by county in Ohio, displaying counties that had at least 10 well buffers within them from 2007 to 2017.

\begin{tabular}{llllllll}
\hline County & $\mathbf{n}$ & $\begin{array}{l}\text { Forest } \\
\text { Mean } \\
(\mathbf{A c})\end{array}$ & $\begin{array}{l}\text { Forest } \\
\text { Std. Dev }\end{array}$ & $\begin{array}{l}\text { Well } \\
\text { Mean } \\
\text { (Ac) }\end{array}$ & $\begin{array}{l}\text { Well } \\
\text { Std. Dev }\end{array}$ & $\begin{array}{l}\text { Grass } \\
\text { Mean } \\
\text { (Ac) }\end{array}$ & $\begin{array}{l}\text { Grass } \\
\text { Std. Dev }\end{array}$ \\
\hline Belmont & 123 & 37.3 & 13.1 & 6.6 & 3.3 & 24.8 & 14.8 \\
Carroll & 122 & 32.7 & 10.7 & 4.4 & 2.3 & 27.4 & 9.7 \\
Columbiana & 55 & 28.4 & 13.7 & 5.0 & 3.4 & 29.6 & 12.4 \\
Guernsey & 51 & 38.7 & 11.2 & 5.3 & 2.0 & 21.8 & 10.3 \\
Harrison & 91 & 36.0 & 11.9 & 5.6 & 2.6 & 22.7 & 11.5 \\
Jefferson & 53 & 29.2 & 11.0 & 3.8 & 2.4 & 31.3 & 11.3 \\
Monroe & 78 & 43.5 & 9.5 & 5.1 & 2.3 & 16.9 & 7.5 \\
Noble & 44 & 42.3 & 10.9 & 4.1 & 1.5 & 20.5 & 7.0 \\
Stark & 13 & 30.1 & 8.9 & 3.6 & 2.3 & 28.2 & 8.7 \\
Trumbull & 12 & 31.2 & 11.4 & 3.2 & 2.4 & 27.9 & 10.4 \\
Tuscarawas & 10 & 34.3 & 10.9 & 9.9 & 3.3 & 18.7 & 11.4 \\
Total & $\mathbf{6 9 1}$ & $\mathbf{3 5 . 5}$ & $\mathbf{1 2 . 6}$ & $\mathbf{5 . 1}$ & $\mathbf{2 . 8}$ & $\mathbf{2 4 . 6}$ & $\mathbf{1 2 . 0}$ \\
\hline
\end{tabular}


Table 3a: Pre-Development land cover percentage by county in Ohio, displaying counties that had at least 10 well buffers within them from 2007 to 2017.

\begin{tabular}{llllllll}
\hline County & $\mathbf{n}$ & $\begin{array}{l}\text { Forest } \\
\text { Mean (\%) }\end{array}$ & $\begin{array}{l}\text { Forest } \\
\text { Std. Dev }\end{array}$ & $\begin{array}{l}\text { Well } \\
\text { Mean (\%) }\end{array}$ & $\begin{array}{l}\text { Well } \\
\text { Std. Dev }\end{array}$ & $\begin{array}{l}\text { Grass } \\
\text { Mean (\%) }\end{array}$ & $\begin{array}{l}\text { Grass } \\
\text { Std. Dev }\end{array}$ \\
\hline Belmont & 123 & 52.4 & 25.3 & 2.2 & 3.3 & 45.5 & 24.1 \\
Carroll & 122 & 42.8 & 17.2 & 1.5 & 2.0 & 55.7 & 16.4 \\
Columbiana & 55 & 48.7 & 22.2 & 4.7 & 7.7 & 46.6 & 19.9 \\
Guernsey & 51 & 59.5 & 23.0 & 2.1 & 5.7 & 38.4 & 21.9 \\
Harrison & 91 & 60.3 & 23.0 & 1.5 & 3.9 & 38.2 & 22.5 \\
Jefferson & 53 & 55.5 & 23.4 & 1.1 & 2.1 & 43.4 & 22.5 \\
Monroe & 78 & 72.3 & 19.6 & 0.7 & 1.2 & 27.0 & 19.1 \\
Noble & 44 & 74.2 & 18.9 & 1.3 & 2.9 & 24.5 & 17.6 \\
Stark & 13 & 42.2 & 24.7 & 2.0 & 2.0 & 55.8 & 24.1 \\
Trumbull & 12 & 39.1 & 20.3 & 10.6 & 8.4 & 50.3 & 17.0 \\
Tuscarawas & 10 & 41.6 & 25.9 & 2.2 & 3.7 & 56.2 & 25.4 \\
Total & $\mathbf{6 9 1}$ & $\mathbf{5 5 . 0}$ & $\mathbf{2 4 . 1}$ & $\mathbf{2 . 1}$ & $\mathbf{4 . 6}$ & $\mathbf{4 3 . 0}$ & $\mathbf{2 3 . 0}$ \\
\hline
\end{tabular}

Table 4a: Post-Development land cover percentage by county in Ohio, displaying counties that had at least 10 well buffers within them from 2007 to 2017.

\begin{tabular}{llllllll} 
County & $\mathbf{n}$ & $\begin{array}{l}\text { Forest } \\
\text { Mean (\%) }\end{array}$ & $\begin{array}{l}\text { Forest } \\
\text { Std. Dev }\end{array}$ & $\begin{array}{l}\text { Well } \\
\text { Mean (\%) }\end{array}$ & $\begin{array}{l}\text { Well } \\
\text { Std. Dev }\end{array}$ & $\begin{array}{l}\text { Grass } \\
\text { Mean (\%) }\end{array}$ & $\begin{array}{l}\text { Grass } \\
\text { Std. Dev }\end{array}$ \\
\hline Belmont & 123 & 55.1 & 17.5 & 9.6 & 3.6 & 35.3 & 16.7 \\
Carroll & 122 & 50.7 & 16.0 & 6.8 & 3.4 & 42.5 & 15.0 \\
Columbiana & 55 & 45.0 & 21.4 & 7.9 & 5.1 & 47.1 & 20.0 \\
Guernsey & 51 & 58.9 & 16.1 & 8.1 & 2.5 & 33.1 & 14.7 \\
Harrison & 91 & 56.2 & 18.6 & 8.7 & 4.0 & 35.2 & 17.4 \\
Jefferson & 53 & 45.6 & 16.9 & 6.0 & 3.6 & 48.5 & 15.8 \\
Monroe & 78 & 66.4 & 11.9 & 7.7 & 3.2 & 25.9 & 11.8 \\
Noble & 44 & 63.1 & 10.7 & 6.0 & 1.7 & 30.9 & 10.5 \\
Stark & 13 & 48.6 & 14.4 & 5.8 & 3.7 & 45.6 & 14.1 \\
Trumbull & 12 & 50.2 & 18.2 & 5.1 & 3.9 & 44.7 & 16.2 \\
Tuscarawas & 10 & 54.4 & 17.2 & 15.8 & 5.1 & 29.8 & 18.6 \\
Total & $\mathbf{6 9 1}$ & $\mathbf{5 4 . 5}$ & $\mathbf{1 8 . 1}$ & $\mathbf{7 . 8}$ & $\mathbf{4 . 0}$ & $\mathbf{3 7 . 7}$ & $\mathbf{1 7 . 5}$ \\
\hline
\end{tabular}


Table 5a: Pre-Development land cover area by county in Pennsylvania, displaying counties that had at least 10 well buffers within them from 2007 to 2017.

\begin{tabular}{llllllll}
\hline County & $\mathbf{n}$ & $\begin{array}{l}\text { Forest } \\
\text { Mean } \\
\text { (Ac) }\end{array}$ & $\begin{array}{l}\text { Forest } \\
\text { Std. } \\
\text { Dev }\end{array}$ & $\begin{array}{l}\text { Well } \\
\text { Mean } \\
\text { (Ac) }\end{array}$ & $\begin{array}{l}\text { Well } \\
\text { Std. } \\
\text { Dev }\end{array}$ & $\begin{array}{l}\text { Grass } \\
\text { Mean } \\
\text { (Ac) }\end{array}$ & $\begin{array}{l}\text { Grass } \\
\text { Std. } \\
\text { Dev }\end{array}$ \\
\hline Allegheny & 17 & 48.2 & 15.9 & 1.6 & 2.6 & 18.6 & 14.8 \\
Armstrong & 32 & 28.1 & 15.5 & 1.1 & 1.1 & 35.1 & 15.3 \\
Beaver & 41 & 40.2 & 11.7 & 0.8 & 1.6 & 22.1 & 11.8 \\
Bradford & 541 & 44.2 & 16.8 & 1.2 & 2.4 & 21.3 & 13.7 \\
Butler & 141 & 31.0 & 12.7 & 0.7 & 1.0 & 32.7 & 12.8 \\
Cameron & 13 & 61.0 & 23.8 & 1.3 & 3.7 & 9.1 & 9.2 \\
Centre & 23 & 59.9 & 17.8 & 0.4 & 1.0 & 8.8 & 9.1 \\
Clarion & 13 & 28.6 & 12.2 & 0.4 & 0.6 & 34.5 & 12.3 \\
Clearfield & 48 & 67.6 & 54.8 & 0.6 & 1.8 & 12.7 & 11.6 \\
Clinton & 25 & 59.5 & 15.0 & 0.7 & 0.9 & 9.2 & 4.4 \\
Elk & 39 & 59.8 & 16.3 & 1.4 & 1.8 & 7.9 & 6.2 \\
Fayette & 68 & 28.0 & 11.9 & 3.0 & 4.3 & 33.4 & 11.8 \\
Greene & 173 & 53.2 & 17.2 & 1.1 & 1.9 & 16.7 & 11.4 \\
Indiana & 17 & 30.0 & 14.7 & 4.9 & 5.5 & 30.2 & 13.1 \\
Jefferson & 19 & 39.3 & 15.3 & 0.6 & 1.2 & 24.1 & 15.9 \\
Lawrence & 23 & 25.4 & 14.2 & 5.2 & 5.4 & 36.9 & 12.3 \\
Lycoming & 238 & 52.7 & 15.5 & 0.5 & 1.2 & 14.2 & 11.0 \\
McKean & 28 & 54.0 & 25.2 & 0.7 & 1.1 & 20.1 & 16.2 \\
Mercer & 16 & 28.2 & 12.1 & 2.6 & 2.7 & 33.1 & 10.7 \\
Potter & 34 & 48.0 & 12.5 & 2.4 & 3.6 & 16.5 & 10.7 \\
Somerset & 10 & 46.7 & 11.7 & 1.1 & 1.6 & 14.7 & 10.1 \\
Sullivan & 78 & 40.2 & 14.0 & 0.6 & 1.0 & 23.6 & 13.2 \\
Susquehanna & 394 & 49.9 & 17.3 & 1.6 & 3.0 & 17.1 & 13.0 \\
Tioga & 246 & 32.8 & 14.6 & 2.3 & 3.4 & 31.4 & 11.7 \\
Washington & 294 & 42.6 & 16.6 & 0.3 & 1.0 & 26.2 & 14.0 \\
Westmoreland & 59 & 31.0 & 19.7 & 3.2 & 4.8 & 41.6 & 31.4 \\
Wyoming & 80 & 42.8 & 13.2 & 1.6 & 2.6 & 19.8 & 12.5 \\
Total & $\mathbf{2 7 4 1}$ & $\mathbf{4 4 . 0}$ & $\mathbf{1 9 . 6}$ & $\mathbf{1 . 4}$ & $\mathbf{3 . 6}$ & $\mathbf{2 2 . 2}$ & $\mathbf{1 5 . 2}$ \\
\hline
\end{tabular}


Table 6a: Post-Development land cover area by county in Pennsylvania, displaying counties that had at least 10 well buffers within them from 2007 to 2017.

\begin{tabular}{llllllll}
\hline County & $\mathbf{n}$ & $\begin{array}{l}\text { Forest } \\
\text { Mean } \\
\text { (Ac) }\end{array}$ & $\begin{array}{l}\text { Forest } \\
\text { Std. } \\
\text { Dev }\end{array}$ & $\begin{array}{l}\text { Well } \\
\text { Mean } \\
\text { (Ac) }\end{array}$ & $\begin{array}{l}\text { Well } \\
\text { Std. } \\
\text { Dev }\end{array}$ & $\begin{array}{l}\text { Grass } \\
\text { Mean } \\
\text { (Ac) }\end{array}$ & $\begin{array}{l}\text { Grass } \\
\text { Std. } \\
\text { Dev }\end{array}$ \\
\hline Allegheny & 17 & 44.9 & 8.9 & 7.4 & 4.5 & 16.1 & 7.2 \\
Armstrong & 32 & 28.7 & 12.5 & 4.7 & 3.4 & 30.9 & 11.7 \\
Beaver & 41 & 41.8 & 7.1 & 4.5 & 2.1 & 16.8 & 6.7 \\
Bradford & 541 & 41.5 & 14.2 & 3.2 & 2.5 & 22.0 & 12.8 \\
Butler & 141 & 38.3 & 10.3 & 7.3 & 6.1 & 18.7 & 8.8 \\
Cameron & 13 & 48.1 & 18.3 & 5.1 & 3.1 & 18.2 & 9.8 \\
Centre & 23 & 50.7 & 12.6 & 2.4 & 1.7 & 16.0 & 7.0 \\
Clarion & 13 & 35.4 & 8.2 & 7.4 & 4.6 & 20.8 & 9.2 \\
Clearfield & 48 & 58.7 & 48.0 & 2.7 & 2.2 & 19.6 & 13.9 \\
Clinton & 25 & 50.4 & 16.5 & 3.5 & 1.7 & 15.6 & 6.9 \\
Elk & 39 & 50.5 & 15.8 & 4.6 & 1.9 & 14.0 & 8.7 \\
Fayette & 68 & 32.5 & 10.5 & 4.8 & 6.1 & 27.1 & 10.9 \\
Greene & 173 & 45.9 & 13.4 & 4.7 & 3.2 & 20.3 & 10.3 \\
Indiana & 17 & 38.0 & 12.1 & 5.7 & 5.0 & 21.3 & 11.0 \\
Jefferson & 19 & 34.0 & 12.7 & 5.9 & 6.2 & 24.0 & 11.9 \\
Lawrence & 23 & 43.0 & 11.1 & 8.9 & 5.6 & 15.5 & 7.4 \\
Lycoming & 238 & 54.4 & 14.1 & 4.4 & 2.8 & 8.6 & 7.3 \\
McKean & 28 & 61.1 & 23.8 & 3.9 & 1.9 & 9.9 & 7.5 \\
Mercer & 16 & 44.3 & 7.5 & 5.8 & 3.8 & 13.7 & 5.7 \\
Potter & 34 & 42.7 & 10.1 & 2.7 & 3.1 & 21.4 & 10.3 \\
Somerset & 10 & 35.4 & 11.9 & 6.0 & 4.3 & 21.1 & 11.6 \\
Sullivan & 78 & 46.7 & 10.1 & 3.4 & 1.5 & 14.2 & 9.7 \\
Susquehanna & 394 & 43.7 & 15.5 & 6.0 & 3.3 & 18.9 & 9.3 \\
Tioga & 246 & 30.0 & 13.6 & 6.0 & 3.7 & 30.6 & 11.6 \\
Washington & 294 & 36.1 & 13.2 & 4.1 & 2.2 & 29.0 & 10.0 \\
Westmoreland & 59 & 35.1 & 23.4 & 3.5 & 2.5 & 37.1 & 27.6 \\
Wyoming & 80 & 28.2 & 8.7 & 5.4 & 4.1 & 30.6 & 8.1 \\
Total & $\mathbf{2 7 4 1}$ & $\mathbf{4 1 . 4}$ & $\mathbf{1 6 . 8}$ & $\mathbf{5 . 1}$ & $\mathbf{4 . 6}$ & $\mathbf{2 1 . 2}$ & $\mathbf{1 3 . 1}$ \\
\hline
\end{tabular}


Table 7a: Pre-Development land cover percentage by county in Pennsylvania, displaying counties that had at least 10 well buffers within them from 2007 to 2017.

\begin{tabular}{llllllll}
\hline County & $\mathbf{n}$ & $\begin{array}{l}\text { Forest } \\
\text { Mean } \\
(\%)\end{array}$ & $\begin{array}{l}\text { Forest } \\
\text { Std. Dev }\end{array}$ & $\begin{array}{l}\text { Well } \\
\text { Mean } \\
(\%)\end{array}$ & $\begin{array}{l}\text { Well } \\
\text { Std. } \\
\text { Dev }\end{array}$ & $\begin{array}{l}\text { Grass } \\
\text { Mean } \\
(\%)\end{array}$ & $\begin{array}{l}\text { Grass } \\
\text { Std. Dev }\end{array}$ \\
\hline Allegheny & 17 & 70.7 & 23.2 & 2.3 & 3.7 & 26.9 & 20.8 \\
Armstrong & 32 & 43.8 & 24.3 & 1.6 & 1.7 & 54.6 & 23.6 \\
Beaver & 41 & 63.8 & 18.8 & 1.3 & 2.6 & 35.0 & 18.5 \\
Bradford & 541 & 66.4 & 20.1 & 1.8 & 3.5 & 31.9 & 19.5 \\
Butler & 141 & 48.1 & 19.2 & 1.1 & 1.6 & 50.8 & 18.8 \\
Cameron & 13 & 84.5 & 18.9 & 1.9 & 5.6 & 13.6 & 13.8 \\
Centre & 23 & 86.4 & 14.3 & 0.4 & 1.0 & 13.2 & 14.2 \\
Clarion & 13 & 45.0 & 19.1 & 0.7 & 1.0 & 54.3 & 19.2 \\
Clearfield & 48 & 82.4 & 15.4 & 0.8 & 2.7 & 16.8 & 14.6 \\
Clinton & 25 & 85.6 & 6.0 & 0.9 & 0.9 & 13.5 & 6.4 \\
Elk & 39 & 86.3 & 11.0 & 2.0 & 2.5 & 11.7 & 9.5 \\
Fayette & 68 & 43.7 & 18.5 & 4.6 & 6.7 & 51.8 & 16.7 \\
Greene & 173 & 75.0 & 15.0 & 1.6 & 2.9 & 23.4 & 14.5 \\
Indiana & 17 & 46.6 & 23.9 & 7.3 & 8.3 & 46.1 & 19.5 \\
Jefferson & 19 & 61.7 & 24.5 & 0.9 & 1.9 & 37.4 & 24.1 \\
Lawrence & 23 & 37.1 & 18.0 & 7.9 & 8.3 & 55.0 & 17.5 \\
Lycoming & 238 & 78.0 & 16.6 & 0.7 & 1.6 & 21.3 & 16.3 \\
McKean & 28 & 72.6 & 19.9 & 1.0 & 1.6 & 26.4 & 19.4 \\
Mercer & 16 & 43.8 & 18.1 & 4.1 & 4.2 & 52.1 & 17.7 \\
Potter & 34 & 72.0 & 18.4 & 3.4 & 4.9 & 24.6 & 16.0 \\
Somerset & 10 & 74.5 & 17.5 & 1.7 & 2.7 & 23.7 & 16.4 \\
Sullivan & 78 & 62.4 & 21.2 & 0.8 & 1.5 & 36.8 & 20.5 \\
Susquehanna & 394 & 73.0 & 18.6 & 2.3 & 4.4 & 24.7 & 17.4 \\
Tioga & 246 & 48.8 & 19.0 & 3.6 & 5.3 & 47.6 & 17.7 \\
Washington & 294 & 61.6 & 19.2 & 0.5 & 1.4 & 38.0 & 19.1 \\
Westmoreland & 59 & 41.7 & 21.0 & 4.4 & 6.8 & 54.0 & 19.8 \\
Wyoming & 80 & 66.7 & 20.5 & 2.5 & 4.1 & 30.8 & 19.3 \\
Total & $\mathbf{2 7 4 1}$ & $\mathbf{6 4 . 9}$ & $\mathbf{2 2 . 1}$ & $\mathbf{2 . 2}$ & $\mathbf{5 . 4}$ & $\mathbf{3 3 . 0}$ & $\mathbf{2 1 . 2}$ \\
\hline
\end{tabular}


Table 8a: Post-Development land cover percentage by county in Pennsylvania, displaying counties that had at least 10 well buffers within them from 2007 to 2017.

\begin{tabular}{llllllll}
\hline County & $\mathbf{n}$ & $\begin{array}{l}\text { Forest } \\
\text { Mean } \\
(\%)\end{array}$ & $\begin{array}{l}\text { Forest } \\
\text { Std. Dev }\end{array}$ & $\begin{array}{l}\text { Well } \\
\text { Mean } \\
(\%)\end{array}$ & $\begin{array}{l}\text { Well } \\
\text { Std. } \\
\text { Dev }\end{array}$ & $\begin{array}{l}\text { Grass } \\
\text { Mean } \\
(\%)\end{array}$ & $\begin{array}{l}\text { Grass } \\
\text { Std. Dev }\end{array}$ \\
\hline Allegheny & 17 & 66.0 & 13.8 & 10.6 & 6.3 & 23.3 & 9.5 \\
Armstrong & 32 & 44.7 & 19.9 & 7.4 & 5.3 & 47.9 & 18.0 \\
Beaver & 41 & 66.2 & 11.0 & 7.1 & 3.3 & 26.7 & 10.7 \\
Bradford & 541 & 62.4 & 17.5 & 4.9 & 3.9 & 32.6 & 16.5 \\
Butler & 141 & 59.6 & 15.3 & 11.4 & 9.4 & 29.0 & 13.0 \\
Cameron & 13 & 66.7 & 15.1 & 7.0 & 3.6 & 26.3 & 15.2 \\
Centre & 23 & 73.4 & 10.0 & 3.5 & 2.2 & 23.1 & 9.3 \\
Clarion & 13 & 55.7 & 12.8 & 11.7 & 7.4 & 32.6 & 14.2 \\
Clearfield & 48 & 71.1 & 13.8 & 3.4 & 2.2 & 25.5 & 13.5 \\
Clinton & 25 & 71.9 & 11.7 & 5.0 & 2.1 & 23.1 & 11.2 \\
Elk & 39 & 72.7 & 12.9 & 6.9 & 3.0 & 20.4 & 12.7 \\
Fayette & 68 & 50.6 & 16.7 & 7.2 & 7.1 & 42.1 & 16.4 \\
Greene & 173 & 65.0 & 11.5 & 6.6 & 3.7 & 28.4 & 11.2 \\
Indiana & 17 & 58.7 & 19.5 & 8.5 & 6.8 & 32.8 & 17.2 \\
Jefferson & 19 & 53.5 & 20.6 & 9.2 & 9.7 & 37.3 & 17.8 \\
Lawrence & 23 & 63.6 & 9.9 & 13.5 & 8.9 & 22.8 & 9.1 \\
Lycoming & 238 & 80.5 & 12.4 & 6.6 & 4.1 & 12.9 & 11.4 \\
McKean & 28 & 82.0 & 5.9 & 5.4 & 2.6 & 12.7 & 6.1 \\
Mercer & 16 & 69.2 & 10.6 & 9.2 & 6.1 & 21.6 & 9.1 \\
Potter & 34 & 64.0 & 15.0 & 4.1 & 4.8 & 31.9 & 14.8 \\
Somerset & 10 & 56.7 & 19.5 & 9.7 & 7.1 & 33.6 & 18.2 \\
Sullivan & 78 & 72.7 & 15.4 & 5.3 & 2.4 & 22.0 & 14.7 \\
Susquehanna & 394 & 63.5 & 11.9 & 8.9 & 4.7 & 27.7 & 11.7 \\
Tioga & 246 & 44.7 & 17.9 & 9.0 & 5.7 & 46.3 & 17.3 \\
Washington & 294 & 51.9 & 13.0 & 5.9 & 3.2 & 42.2 & 12.6 \\
Westmoreland & 59 & 46.5 & 17.4 & 4.9 & 3.6 & 48.6 & 17.1 \\
Wyoming & 80 & 43.9 & 13.7 & 8.5 & 6.4 & 47.6 & 12.4 \\
Total & $\mathbf{2 7 4 1}$ & $\mathbf{6 1 . 0}$ & $\mathbf{1 8 . 0}$ & $\mathbf{7 . 6}$ & $\mathbf{6 . 3}$ & $\mathbf{3 1 . 4}$ & $\mathbf{1 7 . 6}$ \\
\hline
\end{tabular}


Table 9a: Pre-Development land cover area by county in West Virginia, displaying counties that had at least 10 well buffers within them from 2007 to 2017.

\begin{tabular}{llllllll}
\hline County & $\mathbf{n}$ & $\begin{array}{l}\text { Forest } \\
\text { Mean }(\mathbf{A c})\end{array}$ & $\begin{array}{l}\text { Forest } \\
\text { Std. } \\
\text { Dev }\end{array}$ & $\begin{array}{l}\text { Well } \\
\text { Mean }(\mathbf{A c})\end{array}$ & $\begin{array}{l}\text { Well } \\
\text { Std. } \\
\text { Dev }\end{array}$ & $\begin{array}{l}\text { Grass } \\
\text { Mean }(\mathbf{A c})\end{array}$ & $\begin{array}{l}\text { Grass } \\
\text { Std. } \\
\text { Dev }\end{array}$ \\
\hline Barbour & 12 & 46.1 & 13.3 & 0.9 & 1.2 & 19.1 & 13.1 \\
Brooke & 25 & 44.4 & 13.6 & 0.6 & 0.9 & 19.4 & 13.6 \\
Doddridge & 96 & 61.6 & 15.9 & 0.8 & 1.6 & 5.5 & 7.7 \\
Harrison & 58 & 56.3 & 19.5 & 1.5 & 1.9 & 15.9 & 13.7 \\
Logan & 48 & 61.8 & 16.6 & 0.9 & 1.6 & 5.8 & 5.1 \\
Marion & 30 & 56.0 & 8.2 & 0.6 & 0.8 & 8.1 & 8.4 \\
Marshall & 98 & 51.2 & 15.2 & 1.1 & 2.0 & 14.5 & 11.0 \\
Mason & 15 & 56.8 & 19.9 & 1.1 & 1.7 & 10.5 & 8.9 \\
Mingo & 54 & 62.9 & 31.6 & 0.4 & 1.9 & 12.4 & 18.5 \\
Monongalia & 10 & 57.3 & 13.8 & 0.2 & 0.4 & 10.2 & 14.1 \\
Ohio & 29 & 42.7 & 13.9 & 0.3 & 0.9 & 23.4 & 13.1 \\
Preston & 15 & 46.0 & 11.1 & 0.1 & 0.1 & 17.5 & 12.1 \\
Ritchie & 39 & 55.1 & 10.7 & 0.2 & 0.2 & 9.9 & 9.3 \\
Taylor & 16 & 46.9 & 19.7 & 0.4 & 0.6 & 22.0 & 17.0 \\
Tyler & 54 & 55.8 & 11.7 & 0.2 & 0.5 & 9.3 & 12.5 \\
Upshur & 28 & 53.9 & 14.1 & 2.9 & 3.3 & 8.3 & 8.7 \\
Wetzel & 86 & 58.3 & 8.6 & 0.4 & 0.8 & 7.5 & 6.3 \\
Total & $\mathbf{7 8 0}$ & $\mathbf{5 5 . 8}$ & $\mathbf{1 6 . 9}$ & $\mathbf{0 . 7}$ & $\mathbf{1 . 6}$ & $\mathbf{1 1 . 0}$ & $\mathbf{1 2 . 0}$ \\
\hline
\end{tabular}

Table 10a: Post-Development land cover area by county in West Virginia, displaying counties that had at least 10 well buffers within them from 2007 to 2017.

\begin{tabular}{llllllll}
\hline County & $\mathbf{n}$ & $\begin{array}{l}\text { Forest } \\
\text { Mean }(\mathbf{A c})\end{array}$ & $\begin{array}{l}\text { Forest } \\
\text { Std. } \\
\text { Dev }\end{array}$ & $\begin{array}{l}\text { Well } \\
\text { Mean (Ac) }\end{array}$ & $\begin{array}{l}\text { Well } \\
\text { Std. } \\
\text { Dev }\end{array}$ & $\begin{array}{l}\text { Grass } \\
\text { Mean (Ac) }\end{array}$ & $\begin{array}{l}\text { Grass } \\
\text { Std. } \\
\text { Dev }\end{array}$ \\
\hline Barbour & 12 & 39.7 & 9.0 & 3.3 & 1.5 & 23.0 & 7.8 \\
Brooke & 25 & 36.0 & 11.4 & 3.8 & 1.0 & 24.6 & 11.3 \\
Doddridge & 96 & 51.5 & 13.6 & 3.5 & 1.7 & 12.9 & 7.5 \\
Harrison & 58 & 53.9 & 18.0 & 5.0 & 3.6 & 14.8 & 10.4 \\
Logan & 48 & 59.8 & 16.1 & 0.8 & 1.2 & 8.0 & 4.9 \\
Marion & 30 & 45.3 & 8.2 & 3.0 & 1.7 & 16.4 & 7.7 \\
Marshall & 98 & 43.4 & 12.7 & 3.8 & 3.4 & 19.5 & 8.9 \\
Mason & 15 & 57.3 & 17.6 & 0.4 & 0.4 & 10.7 & 7.1 \\
Mingo & 54 & 59.0 & 29.1 & 1.6 & 2.0 & 15.1 & 14.2 \\
Monongalia & 10 & 41.1 & 14.0 & 5.4 & 3.2 & 21.2 & 12.9 \\
Ohio & 29 & 42.1 & 10.3 & 5.4 & 1.9 & 18.8 & 8.8 \\
Preston & 15 & 39.8 & 10.2 & 2.6 & 1.2 & 21.2 & 10.2 \\
Ritchie & 39 & 47.5 & 8.2 & 3.3 & 1.9 & 14.4 & 6.4 \\
Taylor & 16 & 41.3 & 15.9 & 4.9 & 2.8 & 23.0 & 13.6 \\
Tyler & 54 & 48.6 & 8.0 & 3.6 & 1.9 & 13.1 & 8.4 \\
Upshur & 28 & 44.0 & 13.9 & 3.8 & 3.4 & 17.2 & 10.5 \\
Wetzel & 86 & 50.4 & 7.5 & 3.1 & 1.8 & 12.7 & 5.3 \\
Total & $\mathbf{7 8 0}$ & $\mathbf{4 9 . 4}$ & $\mathbf{1 5 . 5}$ & $\mathbf{3 . 1}$ & $\mathbf{2 . 6}$ & $\mathbf{1 5 . 0}$ & $\mathbf{9 . 7}$ \\
\hline
\end{tabular}


Table 11a: Pre-Development land cover percentage by county in West Virginia, displaying counties that had at least 10 well buffers within them from 2007 to 2017.

\begin{tabular}{llllllll}
\hline County & $\mathbf{n}$ & $\begin{array}{l}\text { Forest } \\
\text { Mean } \\
(\%)\end{array}$ & $\begin{array}{l}\text { Forest } \\
\text { Std. Dev }\end{array}$ & $\begin{array}{l}\text { Well } \\
\text { Mean } \\
(\%)\end{array}$ & $\begin{array}{l}\text { Well } \\
\text { Std. Dev }\end{array}$ & $\begin{array}{l}\text { Grass } \\
\text { Mean } \\
(\%)\end{array}$ & $\begin{array}{l}\text { Grass } \\
\text { Std. Dev }\end{array}$ \\
\hline Barbour & 12 & 69.8 & 19.8 & 1.3 & 1.9 & 28.8 & 19.4 \\
Brooke & 25 & 69.1 & 21.4 & 1.0 & 1.5 & 30.0 & 20.9 \\
Doddridge & 96 & 90.5 & 13.4 & 1.3 & 2.5 & 8.3 & 11.8 \\
Harrison & 58 & 77.4 & 13.3 & 2.0 & 2.3 & 20.7 & 12.7 \\
Logan & 48 & 89.9 & 9.0 & 1.4 & 2.6 & 8.7 & 7.5 \\
Marion & 30 & 86.8 & 13.1 & 0.9 & 1.2 & 12.4 & 12.6 \\
Marshall & 98 & 76.5 & 17.6 & 1.6 & 3.1 & 21.9 & 16.7 \\
Mason & 15 & 82.0 & 15.1 & 1.8 & 2.7 & 16.2 & 13.7 \\
Mingo & 54 & 83.5 & 20.3 & 0.7 & 3.0 & 15.8 & 19.8 \\
Monongalia & 10 & 84.9 & 20.5 & 0.3 & 0.5 & 14.8 & 20.3 \\
Ohio & 29 & 64.3 & 20.5 & 0.4 & 1.4 & 35.3 & 20.1 \\
Preston & 15 & 72.6 & 18.7 & 0.1 & 0.2 & 27.2 & 18.6 \\
Ritchie & 39 & 84.4 & 14.6 & 0.3 & 0.4 & 15.3 & 14.4 \\
Taylor & 16 & 67.0 & 26.7 & 0.6 & 0.9 & 32.4 & 26.1 \\
Tyler & 54 & 85.8 & 18.3 & 0.2 & 0.6 & 14.0 & 18.1 \\
Upshur & 28 & 82.7 & 16.7 & 4.5 & 5.4 & 12.8 & 13.4 \\
Wetzel & 86 & 88.0 & 10.1 & 0.5 & 1.2 & 11.5 & 9.7 \\
Total & $\mathbf{7 8 0}$ & $\mathbf{8 2 . 7}$ & $\mathbf{1 7 . 4}$ & $\mathbf{1 . 1}$ & $\mathbf{2 . 4}$ & $\mathbf{1 6 . 2}$ & $\mathbf{1 6 . 8}$ \\
\hline
\end{tabular}

Table 12a: Post-Development land cover percentage by county in West Virginia, displaying counties that had at least 10 well buffers within them from 2007 to 2017.

\begin{tabular}{llllllll}
\hline County & $\mathbf{n}$ & $\begin{array}{l}\text { Forest } \\
\text { Mean } \\
(\%)\end{array}$ & $\begin{array}{l}\text { Forest } \\
\text { Std. Dev }\end{array}$ & $\begin{array}{l}\text { Well } \\
\text { Mean } \\
(\%)\end{array}$ & $\begin{array}{l}\text { Well } \\
\text { Std. Dev }\end{array}$ & $\begin{array}{l}\text { Grass } \\
\text { Mean } \\
(\%)\end{array}$ & $\begin{array}{l}\text { Grass } \\
\text { Std. Dev }\end{array}$ \\
\hline Barbour & 12 & 60.2 & 13.7 & 5.1 & 2.3 & 34.8 & 11.9 \\
Brooke & 25 & 55.9 & 17.8 & 5.9 & 1.6 & 38.2 & 17.4 \\
Doddridge & 96 & 75.7 & 12.2 & 5.2 & 2.5 & 19.1 & 11.2 \\
Harrison & 58 & 73.8 & 9.1 & 6.8 & 4.1 & 19.4 & 8.5 \\
Logan & 48 & 86.9 & 8.6 & 1.2 & 1.8 & 11.9 & 7.4 \\
Marion & 30 & 70.1 & 12.5 & 4.6 & 2.6 & 25.2 & 11.6 \\
Marshall & 98 & 64.9 & 14.9 & 5.7 & 5.1 & 29.4 & 13.0 \\
Mason & 15 & 83.2 & 10.7 & 0.7 & 0.7 & 16.1 & 10.3 \\
Mingo & 54 & 78.3 & 13.7 & 2.0 & 2.4 & 19.7 & 12.2 \\
Monongalia & 10 & 61.0 & 20.9 & 7.9 & 4.2 & 31.1 & 18.4 \\
Ohio & 29 & 63.4 & 14.6 & 8.2 & 2.9 & 28.4 & 13.5 \\
Preston & 15 & 62.7 & 16.5 & 4.0 & 1.7 & 33.2 & 15.8 \\
Ritchie & 39 & 72.9 & 11.1 & 5.0 & 3.0 & 22.1 & 9.8 \\
Taylor & 16 & 59.2 & 21.5 & 6.9 & 3.6 & 33.9 & 21.2 \\
Tyler & 54 & 74.6 & 12.8 & 5.5 & 2.6 & 19.9 & 12.3 \\
Upshur & 28 & 67.6 & 17.7 & 5.9 & 5.2 & 26.5 & 16.4 \\
Wetzel & 86 & 76.2 & 9.5 & 4.7 & 2.6 & 19.2 & 8.1 \\
Total & $\mathbf{7 8 0}$ & $\mathbf{7 3 . 0}$ & $\mathbf{1 5 . 2}$ & $\mathbf{4 . 7}$ & $\mathbf{3 . 7}$ & $\mathbf{2 2 . 3}$ & $\mathbf{1 3 . 6}$ \\
\hline
\end{tabular}


Table 13a: Land cover area for the Appalachian basin

\begin{tabular}{llllllll} 
Time Period & $\mathbf{n}$ & $\begin{array}{l}\text { Forest } \\
\text { Mean } \\
\text { (ac) }\end{array}$ & $\begin{array}{l}\text { Forest } \\
\text { Std. } \\
\text { Dev }\end{array}$ & $\begin{array}{l}\text { Well } \\
\text { Mean } \\
\text { (ac) }\end{array}$ & $\begin{array}{l}\text { Well } \\
\text { Std. } \\
\text { Dev }\end{array}$ & $\begin{array}{l}\text { Grass } \\
\text { Mean } \\
\text { (ac) }\end{array}$ & $\begin{array}{l}\text { Grass } \\
\text { Std. } \\
\text { Dev }\end{array}$ \\
\hline $\begin{array}{l}\text { Pre- } \\
\text { Development }\end{array}$ & 4212 & 44.9 & 19.5 & 1.3 & 3.2 & 21.1 & 15.7 \\
$\begin{array}{l}\text { Post- } \\
\text { Development }\end{array}$ & 4212 & 41.9 & 16.5 & 4.8 & 4.1 & 20.6 & 12.7 \\
\hline
\end{tabular}

Table 14a: Pre-Development land cover, in acres, of areas within the random 25-ha buffers. The counties selected are the county with the most wells drilled per state.

\begin{tabular}{lllllll} 
County & $\begin{array}{l}\text { Forest } \\
\text { Mean (Ac) }\end{array}$ & $\begin{array}{l}\text { Forest } \\
\text { Std. } \\
\text { Dev }\end{array}$ & $\begin{array}{l}\text { Well } \\
\text { Mean (Ac) }\end{array}$ & $\begin{array}{l}\text { Well } \\
\text { Std. } \\
\text { Dev }\end{array}$ & $\begin{array}{l}\text { Grass } \\
\text { Mean (Ac) }\end{array}$ & $\begin{array}{l}\text { Grass } \\
\text { Std. } \\
\text { Dev }\end{array}$ \\
\hline Belmont & 33.4 & 16.4 & 2.3 & 4.2 & 26.1 & 15.0 \\
Bradford & 49.4 & 8.5 & 0.7 & 0.9 & 11.6 & 8.0 \\
Doddridge & 56.9 & 6.6 & 0.4 & 0.7 & 4.3 & 6.2 \\
\hline
\end{tabular}

Table 15a: Post-Development land cover, in acres, of areas within the random 25-ha buffers outside the estimated production unit. The counties selected are the county with the most wells drilled per state.

\begin{tabular}{lllllll}
\hline County & $\begin{array}{l}\text { Forest } \\
\text { Mean }(\mathbf{A c})\end{array}$ & $\begin{array}{l}\text { Forest } \\
\text { Std. } \\
\text { Dev }\end{array}$ & $\begin{array}{l}\text { Well } \\
\text { Mean }(\mathbf{A c})\end{array}$ & $\begin{array}{l}\text { Well } \\
\text { Std. } \\
\text { Dev }\end{array}$ & $\begin{array}{l}\text { Grass } \\
\text { Mean (Ac) }\end{array}$ & $\begin{array}{l}\text { Grass } \\
\text { Std. } \\
\text { Dev }\end{array}$ \\
\hline Belmont & 44.7 & 9.3 & 1.9 & 3.1 & 15.1 & 7.7 \\
Bradford & 46.9 & 13.7 & 2.2 & 5.3 & 12.6 & 11.5 \\
Doddridge & 56.3 & 5.9 & 0.3 & 0.7 & 5.2 & 5.9 \\
\hline
\end{tabular}

Table 16a: Land cover change across the entire Appalachian basin

\begin{tabular}{lllllll}
\hline County & $\begin{array}{l}\text { Forest to } \\
\text { Impervious } \\
\text { (Mean) }\end{array}$ & $\begin{array}{l}\text { Forest to } \\
\text { Impervious } \\
\text { (Std. Dev) }\end{array}$ & $\begin{array}{l}\text { Grass to } \\
\text { Impervious } \\
\text { (Mean) }\end{array}$ & $\begin{array}{l}\text { Grass to } \\
\text { Impervious } \\
\text { (Std. Dev) }\end{array}$ & $\begin{array}{l}\text { Forest to } \\
\text { Grass } \\
\text { (Mean) }\end{array}$ & $\begin{array}{l}\text { Forest to } \\
\text { Grass } \\
\text { (Std. Dev) }\end{array}$ \\
\hline Total & 2.1 & 2.6 & 2.2 & 2.7 & 9.5 & 7.0 \\
\hline
\end{tabular}


Table 17a: Land cover change across West Virginia, showing only those counties with 10 or more buffers

\begin{tabular}{lllllll}
\hline County & $\begin{array}{l}\text { Forest to } \\
\text { Impervious } \\
\text { (Mean) }\end{array}$ & $\begin{array}{l}\text { Forest to } \\
\text { Impervious } \\
\text { (Std. Dev) }\end{array}$ & $\begin{array}{l}\text { Grass to } \\
\text { Impervious } \\
\text { (Mean) }\end{array}$ & $\begin{array}{l}\text { Grass to } \\
\text { Impervious } \\
\text { (Std. Dev) }\end{array}$ & $\begin{array}{l}\text { Forest to } \\
\text { Grass } \\
\text { (Mean) }\end{array}$ & $\begin{array}{l}\text { Forest to } \\
\text { Grass } \\
\text { (Std. } \\
\text { Dev) }\end{array}$ \\
\hline Barbour & 1.3 & 1.1 & 1.8 & 1.6 & 10.2 & 6.2 \\
Brooke & 1.4 & 1.5 & 2.2 & 1.5 & 9.2 & 3.6 \\
Doddridge & 2.8 & 1.5 & 0.6 & 1.2 & 9.6 & 4.3 \\
Harrison & 2.1 & 1.7 & 2.4 & 2.6 & 6.9 & 4.9 \\
Logan & 0.3 & 0.3 & 0.1 & 0.2 & 5.6 & 2.8 \\
Marion & 2.1 & 1.8 & 0.7 & 0.9 & 10.7 & 5.2 \\
Marshall & 1.8 & 2.6 & 1.7 & 1.9 & 8.7 & 5.8 \\
Mason & 0.1 & 0.2 & 0.2 & 0.2 & 3.1 & 2.5 \\
Mingo & 0.5 & 0.5 & 0.9 & 1.8 & 8.4 & 6.7 \\
Monongalia & 4.0 & 2.3 & 1.3 & 1.9 & 13.6 & 4.5 \\
Ohio & 1.7 & 1.5 & 3.7 & 2.3 & 4.3 & 2.4 \\
Preston & 1.1 & 0.9 & 1.5 & 1.4 & 8.5 & 3.1 \\
Ritchie & 2.0 & 1.5 & 1.2 & 1.5 & 8.8 & 4.6 \\
Taylor & 2.3 & 2.7 & 2.5 & 2.2 & 6.3 & 3.9 \\
Tyler & 2.3 & 1.7 & 1.2 & 1.7 & 7.5 & 4.2 \\
Upshur & 2.0 & 2.0 & 0.8 & 1.0 & 9.4 & 3.5 \\
Wetzel & 1.7 & 1.5 & 1.3 & 1.5 & 8.3 & 4.1 \\
Total & $\mathbf{1 . 7}$ & $\mathbf{1 . 8}$ & $\mathbf{1 . 2}$ & $\mathbf{1 . 8}$ & $\mathbf{7 . 9}$ & $\mathbf{4 . 9}$ \\
\hline
\end{tabular}

Table 18a: Land cover change across Ohio, showing only those counties with 10 or more buffers

\begin{tabular}{lllllll}
\hline County & $\begin{array}{l}\text { Forest to } \\
\text { Imperviou } \\
\text { s (Mean) }\end{array}$ & $\begin{array}{l}\text { Forest to } \\
\text { Imperviou } \\
\text { s (Std. } \\
\text { Dev) }\end{array}$ & $\begin{array}{l}\text { Grass to } \\
\text { Imperviou } \\
\text { s(Mean) }\end{array}$ & $\begin{array}{l}\text { Grass to } \\
\text { Imperviou } \\
\text { s (Std. } \\
\text { Dev) }\end{array}$ & $\begin{array}{l}\text { Forest to } \\
\text { Grass } \\
\text { (Mean) }\end{array}$ & $\begin{array}{l}\text { Forest to } \\
\text { Grass } \\
\text { (Std. Dev) }\end{array}$ \\
\hline Belmont & 1.6 & 1.9 & 4.4 & 3.0 & 6.3 & 4.8 \\
Carroll & 0.8 & 0.9 & 3.2 & 2.2 & 4.6 & 2.7 \\
Columbiana & 1.6 & 2.3 & 2.6 & 1.6 & 9.2 & 8.7 \\
Guernsey & 1.4 & 1.5 & 3.4 & 2.3 & 5.6 & 3.7 \\
Harrison & 1.8 & 1.8 & 3.4 & 2.4 & 6.2 & 5.0 \\
Jefferson & 1.2 & 1.1 & 2.4 & 2.0 & 10.8 & 7.1 \\
Monroe & 2.1 & 2.2 & 2.7 & 2.0 & 7.7 & 4.1 \\
Noble & 2.1 & 1.5 & 1.7 & 1.4 & 10.9 & 5.2 \\
Stark & 1.0 & 1.0 & 1.9 & 1.9 & 10.8 & 7.5 \\
Trumbull & 0.3 & 0.6 & 2.2 & 2.2 & 3.5 & 3.9 \\
Tuscarawas & 1.2 & 1.8 & 8.1 & 3.0 & 3.6 & 2.1 \\
Total & $\mathbf{1 . 5}$ & $\mathbf{1 . 7}$ & $\mathbf{3 . 2}$ & $\mathbf{2 . 5}$ & $\mathbf{6 . 9}$ & $\mathbf{5 . 5}$ \\
\hline
\end{tabular}


Table 19a: Accuracy assessment of the supervised classification for the post-development time, using 2017 NAIP imagery, for Pennsylvania.

\begin{tabular}{llllll}
\hline \multirow{2}{*}{ Map } & \multicolumn{3}{c}{ Reference } & \multirow{2}{*}{ Row Total } & User's accuracy \\
\cline { 2 - 5 } & Well & Grass & Forest & & \\
\hline Well & 27 & 0 & 0 & 27 & 100 \\
Grass & 0 & 23 & 4 & 27 & 85 \\
Forest & 3 & 7 & 26 & 36 & 72 \\
Column Total & 30 & 30 & 30 & 90 & \\
Producer's accuracy & 90 & 77 & 87 & & \\
\hline
\end{tabular}

Table 20a: Accuracy assessment of the supervised classification for the post-development time, using 2016 NAIP imagery, for West Virginia.

\begin{tabular}{llllll} 
& \multicolumn{4}{c}{ Reference } & \\
\cline { 2 - 5 } & Well & Grass & Forest & Row Total & User's accuracy \\
\hline Well & 29 & 0 & 0 & 29 & 100 \\
Grass & 1 & 26 & 0 & 27 & 96 \\
Forest & 0 & 4 & 30 & 34 & 88 \\
Column Total & 30 & 30 & 30 & 90 & \\
Producer's accuracy & 97 & 87 & 100 & &
\end{tabular}

Table 21a: Accuracy assessment of the supervised classification for the pre-development time, using 2009 NAIP imagery, for Ohio.

\begin{tabular}{llllll} 
& \multicolumn{3}{c}{ Reference } & \\
\cline { 2 - 5 } & Well & Grass & Forest & Row Total & User's accuracy \\
\hline Well & 4 & 1 & 0 & 5 & 80 \\
Grass & 0 & 43 & 2 & 45 & 96 \\
Forest & 0 & 4 & 36 & 40 & 90 \\
Column Total & 4 & 48 & 38 & 90 & \\
Producer's accuracy & 100 & 90 & 95 & &
\end{tabular}


Table 22a: Accuracy assessment of the supervised classification for the random 25-ha buffers, using 2008 NAIP imagery, of Bradford county, Pennsylvania.

\begin{tabular}{llllll} 
& \multicolumn{5}{c}{ Reference } \\
\cline { 2 - 5 } Map & Well & Grass & Forest & Row Total & User's accuracy \\
\hline Well & 10 & 0 & 0 & 10 & 100 \\
Grass & 0 & 4 & 0 & 4 & 100 \\
Forest & 0 & 6 & 10 & 16 & 63 \\
Column Total & 10 & 10 & 10 & 30 & \\
Producer's accuracy & 100 & 40 & 100 & &
\end{tabular}

Table 23a: Accuracy assessment of the supervised classification for the random 25-ha buffers, using 2007 NAIP imagery, of Doddridge county, West Virginia.

\begin{tabular}{|c|c|c|c|c|c|}
\hline \multirow[b]{2}{*}{ Map } & \multicolumn{3}{|c|}{ Reference } & \multirow[b]{2}{*}{ Row Total } & \multirow[b]{2}{*}{ User's accuracy } \\
\hline & Well & Grass & Forest & & \\
\hline Well & 9 & 0 & 0 & 9 & 100 \\
\hline Grass & 0 & 8 & 0 & 8 & 100 \\
\hline Forest & 1 & 2 & 10 & 13 & 77 \\
\hline Column Total & 10 & 10 & 10 & 30 & \\
\hline Producer's accuracy & 90 & 80 & 100 & & \\
\hline
\end{tabular}

Table 24a: Accuracy assessment of the supervised classification for the random 25-ha buffers, using 2009 NAIP imagery, of Belmont county, Ohio.

\begin{tabular}{llllll} 
& \multicolumn{3}{c}{ Reference } & \\
\cline { 2 - 5 } Map & Well & Grass & Forest & Row Total & User's accuracy \\
\hline Well & 10 & 0 & 0 & 10 & 100 \\
Grass & 0 & 10 & 1 & 11 & 91 \\
Forest & 0 & 0 & 9 & 9 & 100 \\
Column Total & 10 & 10 & 10 & 30 & \\
Producer's accuracy & 100 & 100 & 90 & & \\
\hline
\end{tabular}


Table 25a: Accuracy assessment of the supervised classification for the undeveloped 25-ha buffers, using 2017 NAIP imagery, of Bradford county, Pennsylvania.

\begin{tabular}{llllll}
\hline \multirow{2}{*}{ Map } & \multicolumn{4}{c}{ Reference } & \\
\cline { 2 - 5 } & Well & Grass & Forest & Row Total & User's accuracy \\
\hline Well & 29 & 0 & 0 & 29 & 100 \\
Grass & 0 & 23 & 1 & 24 & 96 \\
Forest & 1 & 7 & 29 & 37 & 78 \\
Column Total & 30 & 30 & 30 & 90 & \\
Producer's accuracy & 97 & 77 & 97 & & \\
\hline
\end{tabular}

Table 26a: Accuracy assessment of the supervised classification for the undeveloped 25-ha buffers, using 2016 NAIP imagery, of Doddridge county, West Virginia.

\begin{tabular}{llllll}
\hline \multirow{2}{*}{ Map } & \multicolumn{4}{c}{ Reference } & \\
\cline { 2 - 5 } & Well & Grass & Forest & Row Total & User's accuracy \\
\hline Well & 7 & 0 & 0 & 7 & 100 \\
Grass & 3 & 6 & 0 & 9 & 67 \\
Forest & 0 & 4 & 10 & 14 & 71 \\
Column Total & 10 & 10 & 10 & 30 & \\
Producer's accuracy & 70 & 60 & 100 & & \\
\hline
\end{tabular}

Table 27a: Accuracy assessment of the supervised classification for the undeveloped 25-ha buffers, using 2017 NAIP imagery, of Belmont county, Ohio.

\begin{tabular}{llllll} 
& \multicolumn{3}{c}{ Reference } & \\
\cline { 2 - 5 } Map & Well & Grass & Forest & Row Total & User's accuracy \\
\hline Well & 28 & 0 & 0 & 28 & 100 \\
Grass & 0 & 24 & 5 & 29 & 83 \\
Forest & 2 & 6 & 25 & 33 & 76 \\
Column Total & 30 & 30 & 30 & 90 & \\
Producer's accuracy & 93 & 80 & 83 & &
\end{tabular}

